Article

\title{
Increasing Dairy Sustainability with Integrated Crop-Livestock Farming
}

\author{
Susanne Wiesner ${ }^{1,2,3, * \mathbb{C}}$, Alison J. Duff ${ }^{2}{ }^{\mathbb{D}}$, Ankur R. Desai ${ }^{3}$ and Kevin Panke-Buisse ${ }^{2}(\mathbb{D}$ \\ 1 Oak Ridge Institute for Science and Education, Oak Ridge, TN 37830, USA \\ 2 U.S. Dairy Forage Research Center, USDA Agricultural Research Service, Madison, 53706, Prairie du Sac, \\ WI 53578, USA; alison.duff@usda.gov (A.J.D.); kevin.panke-buisse@usda.gov (K.P.-B.) \\ 3 Department of Atmospheric and Oceanic Sciences, University of Wisconsin, Madison, WI 53706, USA; \\ desai@aos.wisc.edu \\ * Correspondence: swiesner2@wisc.edu
}

Received: 31 December 2019; Accepted: 17 January 2020; Published: 21 January 2020

check for updates

\begin{abstract}
Dairy farms are predominantly carbon sources, due to high livestock emissions from enteric fermentation and manure. Integrated crop-livestock systems (ICLSs) have the potential to offset these greenhouse gas (GHG) emissions, as recycling products within the farm boundaries is prioritized. Here, we quantify seasonal and annual greenhouse gas budgets of an ICLS dairy farm in Wisconsin USA using satellite remote sensing to estimate vegetation net primary productivity (NPP) and Intergovernmental Panel on Climate Change (IPCC) guidelines to calculate farm emissions. Remotely sensed annual vegetation NPP correlated well with farm harvest NPP $\left(R^{2}=0.9\right)$. As a whole, the farm was a large carbon sink, owing to natural vegetation carbon sinks and harvest products staying within the farm boundaries. Dairy cows accounted for $80 \%$ of all emissions as their feed intake dominated farm feed supply. Manure emissions (15\%) were low because manure spreading was frequent throughout the year. In combination with soil conservation practices, ICLS farming provides a sustainable means of producing nutritionally valuable food while contributing to sequestration of atmospheric $\mathrm{CO}_{2}$. Here, we introduce a simple and cost-efficient way to quantify whole-farm GHG budgets, which can be used by farmers to understand their carbon footprint, and therefore may encourage management strategies to improve agricultural sustainability.
\end{abstract}

Keywords: dairy farm; carbon budget; remote sensing; net primary productivity; greenhouse gas emissions

\section{Introduction}

Agricultural landscapes cover $\sim 37 \%$ of the terrestrial surface on Earth. In the U.S. alone, nearly $45 \%$ of the terrestrial land surface is used for agricultural production-of which corn, soybeans and wheat crops make up $~ 35 \%, 36 \%$ and $18 \%$ of the land area, respectively [1]. Global agricultural management has decreased soil organic carbon pools by $25 \%-78 \%$ over the last 200 years, depending on the soil type [2-4]. Recent trends towards more extensive and more concentrated livestock facilities, specifically dairy farms [5-8], have come at an environmental cost [9].

Larger herd sizes are more efficient in terms of milk production [5], but they present challenges for achieving mass nutrient balances and offsetting emissions [10], as larger herds are concentrated on a smaller land base. The shift to larger herd sizes is also correlated with landscape simplification, owing to an increasing reliance on fewer high-yield annuals in the dairy diet. Declines in landscape and cropping diversity are further linked to decreases in ecosystem services [11-13], as well as lower resilience to weather extremes, such as droughts or flooding. Despite observed decreases in global agricultural land coverage [14], the sector is one of the largest contributors to nutrient runoff into 
aquatic systems [15-19], a major source for greenhouse gas release to the atmosphere $[20,21]$ and a large factor in soil degradation [12]. Livestock production, specifically dairy, has been identified as a leading contributor to greenhouse gas emissions [22,23].

Integrated crop-livestock systems (ICLSs) comprise a variety of practices that can reduce greenhouse gas (GHG) emissions and water pollution [24] and enhance C-, N-, and P-cycling [25-27], through appropriate fertilizer and manure applications. Practices may include grazing livestock on crops and crop residues, planting forage cover crops, and trading animal waste and crop products among farms $[11,28]$. ICLSs have greater potential to mimic the structure and function of natural ecosystems [29-31], with less reliance on external inputs.

In addition to decreasing GHG emissions of livestock, efforts to improve agroecosystem sustainability may create new opportunities for income derived from on-farm production of ecosystem services. However, estimating GHG budgets of farms can be challenging and is often accompanied by large uncertainties, especially if no detailed knowledge about farm management practices are available [32]. Life cycle assessments (LCA) using a variety of farm-scale models have been used to understand greenhouse gas sources and to compare and contrast different dairy production systems of varying extents (herd size and crop production acreage) [23]. However, these models range from simple to highly complex interactions, may be highly regionally specific, and are often subject to extensive calibration and validation [23]. Furthermore, the variability in landscape productivity is often ignored, because it is particularly difficult to quantify in more complex terrain and landscapes [33]. Satellite remote sensing techniques provide a cost-efficient way to significantly decrease data collection efforts while simultaneously providing more information on vegetation productivity and emission variability over time and space [34].

To test this approach, here, we quantify ecosystem services provided by an ICLS in Wisconsin, to understand how farm management affects environmental sustainability at different spatial and temporal scales. For our first objective we evaluate the validity of quantifying the farm carbon sink potential of the land base of a dairy farm in Wisconsin using satellite remote sensing techniques, by comparing these with harvest totals for 2018. The novelty of this work compared to published work is that this approach included the spatial and temporal estimation of ecosystem respiration, and gross and net primary production (NPP) of carbon of the farm land cover-croplands and forest, shrub and grassland vegetation - using remote sensing data. For our second objective, we evaluate the seasonal and annual GHG offset potential of an ICLS farm in Wisconsin, by combining NPP estimates with observations of emissions from enteric fermentation, and manure and field applications using the Tier 2 guidelines from the Intergovernmental Panel on Climate Change (IPCC).

\section{Materials and Methods}

\subsection{Study Site}

The U.S. Dairy Forage Research Center (USDFRC) farm is located in Sauk County, Wisconsin, USA. The climate is described as warm summer continental (Dfb, Köppen Climate Classification), with a mean annual temperature of $8{ }^{\circ} \mathrm{C}$, receiving $\sim 880 \mathrm{~mm}$ of precipitation per year. The majority of the soils are characterized as being moderately well drained to excessively drained, with medium textured soils over shallow quartzite rock outcroppings.

The USDFRC farm ( $890 \mathrm{ha})$, which operates jointly with the University of Wisconsin-Madison College of Agricultural and Life Sciences, is located approximately $48 \mathrm{~km}$ northwest of Madison on gently sloping acres bordering the Wisconsin River. The farm is a large-sized dairy for Wisconsin, with approximately 400 dairy cows, in addition to heifers (1-24 months of age) and dry cows ( 350$)$. Crops grown on the farm include corn for grain and silage, alfalfa for silage, soybeans and winter wheat (Figure 1). The farm has several acres of open pasture used to graze heifers for approximately 6 months each year. Livestock housing includes both tie-stall and free-stall barns. Cows are milked three times a 
day. Cows in free-stall barns are fed from a total mixed ration (TMR) wagon. Average milk production is approximately $13,150 \mathrm{~kg}(12,764 \mathrm{~L})$ of milk per cow per year at $3.72 \%$ butterfat and $3.01 \%$ protein.

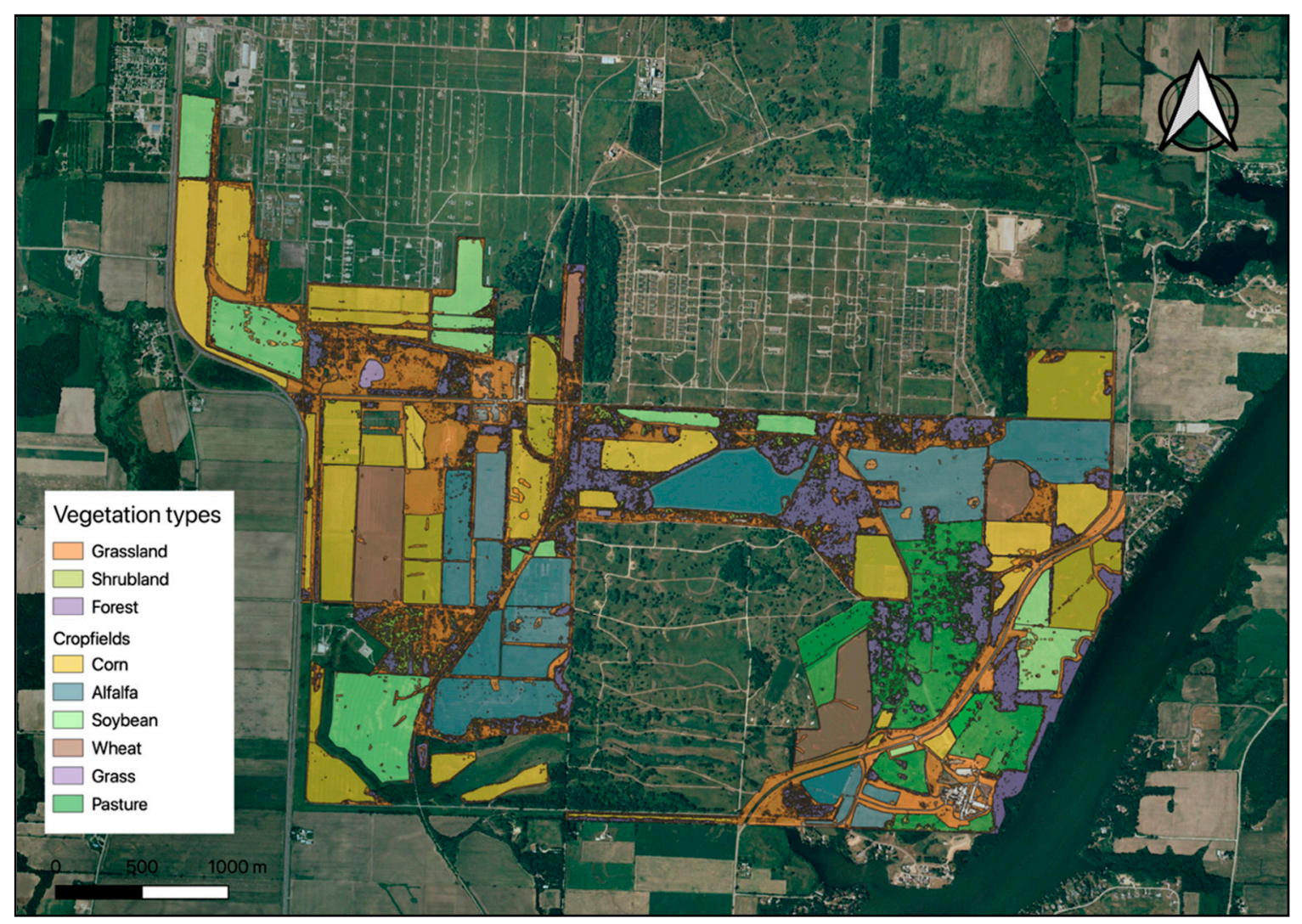

Figure 1. Map of the Dairy Forage Research Center and crop field compositions for 2018 at Prairie du Sac, Sauk County, WI.

\subsection{Meteorological Data}

A weather station installed in January 2018 recorded air temperature (using Onset, Inc. temperature sensor S-TMB-M006 and relative humidity sensor S-THB-M006, attached to a HOBO U30 Station, Onset, Inc., Bourne, MA, USA) and photosynthetic active radiation (PAR) using a quantum sensor (HOBOnet PAR Sensor, Onset, Inc. Bourne, MA, USA) through October 2018. For the remainder of the year, we obtained data from a weather station located in Necedah, Wisconsin, approximately $100 \mathrm{~km}$ north of Prairie du Sac. Necedah air temperature and PAR data were linearly regressed with data collected on site and then missing data for November and December were gap-filled using the respective linear regression $\left(\mathrm{PAR}_{\mathrm{DFRC}}=0.7877 \times \mathrm{PAR}_{\text {Necedah }}+19.54 ; \mathrm{R}^{2}=0.9, p<0.05 \& \mathrm{~T}_{\text {air,DFRC }}=\right.$ $0.8246 \times \mathrm{T}_{\text {air,Necedah }}+0.8953 ; \mathrm{R}^{2}=0.97, p<0.05$ ). Rainfall sums were taken from a nearby National Oceanic and Atmospheric Administrative (NOAA) weather station in Baraboo, WI, located $\sim 20 \mathrm{~km}$ from the farm.

\subsection{Annual Crop Harvest}

Alfalfa was harvested from May throughout August 2018, winter wheat was harvested in July, corn silage and corn for high moisture corn (HMC) in September, and dry corn and soybeans in October. All harvested crops were weighed (in pounds converted to $\mathrm{kg}$ ) and stored on site, with the exception of soybeans, where the majority of the harvest was sold in October 2018. To estimate $\mathrm{NPP}_{\text {Harvest }}(\mathrm{g} \mathrm{C})$, we used harvest index data (HI; established from personal conversation with crop manager; Table 1), dry matter fractions and root: shoot ratios from the literature [35-39], as well as a C conversion factor of $450 \mathrm{~g} \mathrm{C}$ per $\mathrm{kg}$ biomass [38]. Harvest indices for corn and alfalfa were nearly $100 \%$ for aboveground 
biomass as either all aboveground biomass was harvested for silage or residues were bailed and used for silage or bedding on site.

Table 1. Harvest data of dry matter (DM; \%), harvest index (HI; \%), proportion of root to aboveground biomass (in \%), total aboveground biomass $(\mathrm{kg})$, percent $\mathrm{C}$, and estimated harvest, residual and root $\mathrm{C}$, as well as their sum (whole plant $\mathrm{C} ; \mathrm{kg} \mathrm{C}$ ) for the crops of alfalfa, corn (dry, silage and high moisture corn (HMC)), winter wheat and soybeans, grown at Prairie du Sac dairy farm in 2018.

\begin{tabular}{ccccccc}
\hline Crop type & Alfalfa & Corn Silage & Dry Corn & HMC & Wheat & Soybeans \\
\hline DM $(\%)$ & 35 & 35 & 70 & 70 & 87 & 86 \\
\hline HI $(\%)$ & 90 & 85 & 53 & 90 & 90 & 42 \\
\hline $\begin{array}{c}\text { Root from } \\
\text { Aboveground }(\%)\end{array}$ & $120( \pm 30 \%)$ & $21( \pm 30 \%)$ & $21( \pm 30 \%)$ & $21( \pm 30 \%)$ & $90( \pm 30 \%)$ & $19( \pm 30 \%)$ \\
\hline $\begin{array}{c}\text { Total Aboveground } \\
\text { Biomass }(\mathrm{kg})\end{array}$ & $1,052,680.3$ & $1,046,346.4$ & $633,829.3$ & $647,793.5$ & $736,068.4$ & 40403.2 \\
\hline C $(\%)$ & 45 & 45 & 45 & 45 & 45 & 45 \\
\hline Harvest C $(\mathrm{kg})$ & $468,969.1$ & $466,147.3$ & $282,371.0$ & $288,592.0$ & $139,116.9$ & $17,999.6$ \\
\hline Residual C $(\mathrm{kg})$ & 4737.1 & 4708.6 & 2852.2 & 2915.1 & 192113.9 & 181.8 \\
\hline Root C $(\mathrm{kg})$ & $378,964.9$ & $\begin{array}{c}94,171.2 \\
( \pm 30 \%)\end{array}$ & $\begin{array}{c}57,044.6 \\
( \pm 30 \%)\end{array}$ & $\begin{array}{c}58,301.4 \\
( \pm 30 \%)\end{array}$ & $\begin{array}{c}62,933.9 \\
( \pm 30 \%)\end{array}$ & $\begin{array}{c}4181.7 \\
( \pm 30 \%)\end{array}$ \\
\hline Whole Plant C $(\mathrm{kg})$ & $\begin{array}{c}852,671.1 \\
( \pm 16.4 \%)\end{array}$ & $\begin{array}{c}565,027.1 \\
( \pm 5.2 \%)\end{array}$ & $\begin{array}{c}342,267.8 \\
( \pm 5.2 \%)\end{array}$ & $\begin{array}{c}349,808.5 \\
( \pm 5.2 \%)\end{array}$ & $\begin{array}{c}394,164.7 \\
( \pm 8.6 \%)\end{array}$ & $\begin{array}{c}22,363.2 \\
( \pm 4.8 \%)\end{array}$ \\
\hline
\end{tabular}

\subsection{Remote Sensing Gross Primary Productivity}

We obtained satellite data from Landsat 8 and the Moderate Resolution Imaging Spectroradiometer (MODIS) for 2018 to estimate gross ecosystem productivity (GPP; $\mathrm{g} \mathrm{C} \mathrm{m}^{-2}$ ) using the satellite-based Vegetation Photosynthesis model (VPM) developed by Xiao et al. [40]. Downscaled MODIS data (from 250 by $250 \mathrm{~m}$ to Landsat 8 resolution of $30 \mathrm{~m}$ by $30 \mathrm{~m}$ ) were used to gap-fill missing monthly Landsat scenes (e.g., missing due to cloud obstruction or sensor failures). Because MODIS data have a higher temporal resolution (1-8 days) the probability for cloud obstruction of particular scenes is lower compared to Landsat 8 (16 days). The model simulates GPP using the enhanced vegetation index (EVI), the land surface water index (LSWI) and land surface temperature (LST), as well as ground observations of PAR. Landsat 8 EVI scenes (temporal resolution of 16 days) were directly downloaded from USGS Earth Resources Observation and Science (EROS) Center Science Processing Architecture (ESPA). EVI from Landsat and MODIS is estimated as follows:

$$
E V I=2.5 \times \frac{(N I R-R e d)}{(N I R+6 \times \operatorname{Red}-7.5 \times B+1)}
$$

where NIR is the near-infrared band 5 (Landsat 8) and 2 (MODIS), Red the red band 4 (Landsat 8) and 1 (MODIS), and B the blue band 2 on Landsat 8 and band 3 on MODIS. All Landsat scenes were filtered using the quality assurance (QA) band ("pixel_qa"). MODIS EVI was estimated from raw surface reflectance data, downloaded from ORNL DAAC using the MODIS/VIIRS subsets tool, which were first filtered using the QC bands. Landsat LSWI, to describe liquid water contents in vegetation canopies [41], was estimated from Landsat surface reflectance metadata, downloaded from USGS EROS center, using the ToLSWI function of the rLandsat8 package in R. The function estimates LSWI as follows:

$$
L S W I=\frac{(N I R-S W I R 1)}{(N I R+S W I R 1)}
$$

where SWIR1 is the shortwave infrared band 6. For MODIS LSWI and EVI were estimated using the lswi and evi functions in the water package in R, where SWIR is band 6 on MODIS satellites. 
Landsat LST was estimated by first converting spectral radiance to brightness temperature using the thermal constants provided in the raw Landsat metadata scenes and the function ToAtSatelliteBrightnessTemperaure in the rLandsat8 package. Brightness temperature (BT) was then converted to LST following the approach of Sobrino et al. [42]:

$$
L S T=\frac{B T}{\left[1+\lambda \times\left(\frac{B T}{P}\right) \times \ln (\varepsilon)\right]}
$$

where $P=h \times \frac{c}{s}=14388\left(\mathrm{um} \mathrm{K}^{-1}\right)$, with $\mathrm{h}$ as the Planck constant $\left(6.62610-34 \mathrm{~J} \mathrm{~s}^{-1}\right)$, s the Boltzmann constant (1.38 10-23 $\left.\mathrm{J} \mathrm{K}^{-1}\right)$ and $\mathrm{c}$ the velocity of light (2.998 10-8 $\left.\mathrm{m} \mathrm{s}^{-1}\right)$. The parameter $\lambda$ describes the effective wavelength for the thermal bands, which is 10.6 for band 10 of Landsat 8 . The parameter $\varepsilon$ is emissivity of the land surface, calculated using the Normalized Difference Vegetation Index (NDVI) to describe the proportion of vegetation $(P V)$ calculated as follows:

$$
P V=\left[\frac{\left(N D V I-N D V I_{\min }\right)}{\left(N D V I_{\max }-N D V I_{\min }\right)}\right]^{2}
$$

where $\mathrm{NDVI}_{\min }$ was assumed to be 0.2 and $\mathrm{NDVI}_{\max } 0.86$ [42]. NDVI was estimated using the ToNDVI function of the rLandsat8 package, which uses bands 4 (RED) and 5 (NIR) to calculate NDVI as $N D V I=(\mathrm{NIR}-\mathrm{Red}) /(\mathrm{NIR}+\mathrm{Red})$. Emissivity $(\varepsilon)$ was calculated as $\varepsilon=\varepsilon_{V} * P V+\varepsilon_{s}(1-P V)+0.005$, where $\varepsilon_{\mathrm{V}}$ is vegetation emissivity (0.973) and $\varepsilon_{\mathrm{S}}$ soil emissivity (0.991) and 0.005 represents surface roughness, here assumed to be constant [43]. MODIS LST (temporal resolution of 8 days) was downloaded from ORNL DAAC using the MODIS/VIIRS subsets tool.

The VPM model estimates GPP using PAR (as the sum for the 16 days surrounding Landsat or 8 days for MODIS scenes; see acquisition dates in Supplementary Information Table S1), the light use efficiency for the different vegetation types ( $\varepsilon_{\mathrm{g}}$ in $\left.\mathrm{g} \mathrm{C} \mathrm{mol}^{-1} \mathrm{PAR}\right)$, as well as EVI, LSWI and LST as follows:

$$
G P P_{V P M}=\varepsilon_{g} \times F P A R_{c h l} \times P A R
$$

where $F P A R_{c h l}$ is the fraction of PAR absorbed by chlorophyll calculated as $F P A R_{c h l}=a \times E V I$, where $a=1$ following Xiao et al. [40,44] and Dong et al. [45]. The light use efficiency $\varepsilon_{\mathrm{g}}$ is derived from the relationship of maximum quantum yield $\left(\varepsilon_{0} ; \mathrm{g} \mathrm{C} \mathrm{mol}^{-1} \mathrm{PAR}\right.$; Supplementary Materials Table S2), taken from literature values [46], scalars of temperature $\left(T_{\text {scalar }}\right)$ and water stressors to the vegetation $\left(W_{\text {scalar }}\right.$ and $P_{\text {scalar }}$ ) as follows:

$$
\varepsilon_{g}=\varepsilon_{0} \times T_{\text {scalar }} \times W_{\text {scalar }} \times P_{\text {scalar }}
$$

where $T_{\text {scalar }}\left(0>T_{\text {scalar }}<1\right)$ is estimated as:

$$
T_{\text {scalar }}=\frac{\left(T-T_{\min }\right)\left(T-T_{\max }\right)}{\left(T-T_{\min }\right)\left(T-T_{\max }\right)-\left(T-T_{\text {opt }}\right)^{2}}
$$

with $T_{\min }, T_{\max }$ and $T_{\text {opt }}$ as the minimum, maximum and optimum temperatures for photosynthetic activity, here set to be $-1,48$ and $30^{\circ} \mathrm{C}$ for Wisconsin, respectively, according to [47] and T is LST from Landsat or MODIS converted from $\mathrm{K}$ to ${ }^{\circ} \mathrm{C}$. When air temperature falls below $T_{\text {min }}, T_{\text {scalar }}$ is set to 0 [40]. $W_{\text {scalar }}\left(0>W_{\text {scalar }}<1\right)$ is estimated as follows:

$$
W_{\text {scalar }}=\frac{(1+L S W I)}{\left(1+L S W I_{\max }\right)}
$$

where $L S W I_{\max }$ is the maximum LSWI within the growing season, set to 0.78 for 2018 in this study. The scalar $P_{\text {scalar }}$ is estimated as:

$$
P_{\text {scalar }}=\frac{(1+L S W I)}{2} \text {. }
$$


Each crop field and vegetation type (forest, shrub and grass) was assigned a $\varepsilon_{0}$ (Supplementary Materials Table S2) to generate a raster of maximum quantum yield.

Final GPP raster time series from Landsat were first gap-filled via the approxNA function from the raster $\mathrm{R}$ package and then using GPP MODIS raster time series. The approxNA function estimates missing pixel values through linear interpolation among time series of pixels from consecutive layers (i.e., 16 day Landsat or MODIS GPP raster timeseries). For NA pixels in Landsat scenes, which could not be filled using the approxNA function, we gap-filled data using a linear regression between Landsat and downscaled MODIS pixels. Because MODIS GPP raster time series were 8 day products, we first summed up 2 consecutive GPP raster products to match Landsat 16 day GPP raster timeseries products. After that, MODIS pixel data were resampled from a cell resolution of $250 \mathrm{~m}$ by $250 \mathrm{~m}$ to match the cell resolution of Landsat GPP rasters $(30 \mathrm{~m}$ by $30 \mathrm{~m}$ ) and to align cell centers among the different products using bilinear interpolation. Bilinear interpolation uses the weighted average of four nearest cells of the input raster to determine the cell value for the resampled output raster. We then linearly regressed pixels of each Landsat GPP product with the respective MODIS product by setting the intercept to 0 and thus obtaining a distinct slope $(m)$ for each scene (Landsat GPP pixel $x_{x, y}=$ $m \times$ MODIS GPP pixel $_{x, y}$, where $\mathrm{x}$ and $\mathrm{y}$ denote latitudinal and longitudinal coordinates). Landsat 8 raster pixels were then gap-filled using the respective linear regression for each timepoint.

\subsection{Remote Sensing of Ecosystem Respiration}

Spatial ecosystem respiration $\left(R_{e c o}\right)$ for the farm was estimated using a remote sensing model developed by Gao et al. [48]. The model estimates $R_{\text {eco }}$ from GPP and crop biomass decomposition, which depends closely on temperature. $R_{\text {eco }}$ (Equation 10) was calculated using a constant fraction of GPP that is assumed to be spend on respiration (here $a=0.25$, following Warring [49] and Peichl et al. [50]; resembling a factor of NPP:GPP of 0.4-0.7), and a reference respiration rate $\left(R_{\text {ref }}\right)$, which was set to $2.86 \mathrm{~g} \mathrm{C} \mathrm{m}^{-2}$ for a reference temperature of $10^{\circ} \mathrm{C}\left(T_{\text {ref }}\right)$, estimated from eddy covariance and soil respiration data (data not shown). Ecosystem respiration was then calculated as follows:

$$
R_{e c o}=a \times G P P+R_{r e f} \times e^{E_{0} \times \frac{1}{T_{r e f}-T_{0}}-\frac{1}{T-T_{0}}}
$$

where E0 is the temperature sensitivity of activation energy of respiration $\left(263.59 \mathrm{~K}\right.$, converted to $\left.{ }^{\circ} \mathrm{C}\right)$, estimated using the R package ReddyProc [51] and eddy covariance data of net ecosystem exchange of $\mathrm{CO}_{2}$ which were available from the site from October 2018 through June 2019. The parameter $\mathrm{T} 0$ is the minimum temperature for respiration $\left({ }^{\circ} \mathrm{C}\right)$, which was set to $-46.02{ }^{\circ} \mathrm{C}$, following Gao et al. [48] and $\mathrm{T}$ is Landsat/MODIS Land Surface Temperature $\left({ }^{\circ} \mathrm{C}\right)$. Similar to GPP calculations, we gapfilled $\mathrm{R}_{\text {eco }}$ timeseries via the approxNA function and then used resampled MODIS $\mathrm{R}_{\mathrm{eco}}$ raster time series to gapfill Landsat NA pixels using a linear regression between Landsat and MODIS pixels.

\subsection{Emission Inventories}

\subsubsection{Cattle Emissions}

We obtained monthly herd inventory data from the dairy farm for 2018. Cattle were primarily fed crops grown on site with the addition of protein mixes, lactation minerals, beet pulp molasses, canola meal, calf starters, Geobond, and Reashure, depending on the cattle group. Dairy cows were fed alfalfa silage $(29.95 \%)$, corn silage $(29.8 \%)$ high moisture corn $(23.2 \%)$, roasted soybeans $(7.4 \%$ of diet), canola meal (8.3\%), and lactation minerals $(2.4 \%)$. Dry cows were fed corn silage $(42.4 \%)$, grass hay $(20 \%)$, wheat straw $(9.2 \%)$, canola meal $(8.4)$, roasted soybeans $(6.3 \%)$, HMC $(4.5 \%)$, minerals $(\sim 2 \%)$ and protein mixes $(\sim 2 \%)$. Heifers were fed a diet consisting of alfalfa silage $(47 \%)$, corn silage $(22.3 \%)$, wheat straw $(9.3 \%)$, and minerals $(\sim 1.5 \%)$ and special diets for calves (i.e., calf starter $\sim 6 \%$ ).

We obtained nutrient values for the diets from laboratory analysis for forage taken throughout the year of 2018 (Dairyland; Table 2), and for TMR from the literature [52-54] for ingredients where no 
nutrient information was available (i.e., calf starters, canola meal, beet pulp and mineral additions). Average nutrients by month and cow class were estimated using a weighted average, to account for different percent contributions to each diet. Monthly manure emissions were then estimated following Appuhamy et al. [55] by first calculating volatile solid excretion (VS; $\mathrm{kg} \mathrm{month}^{-1}$ ) of all cattle on farm. Volatile solids are biodegradable and nonbiodegradable fractions of organic matter in manure [55]. Monthly VS was calculated as a function of nutritional intake (Table 2):

$$
V S=-1.201+0.402 \times O M I+0.036 \times N D F-0.024 \times C P
$$

where OMI is organic matter intake $\left(\mathrm{kg} \mathrm{month}^{-1}\right)$, calculated as $85 \%$ from total monthly dry matter intake (DM) for each cattle type (Table 2), CP (\%) is crude protein and NDF (\%) is non-digestible fiber, both estimated as weighted averages for diets of each cow class.

Table 2. Average monthly nutritional dietary numbers and their standard deviations in parentheses by cattle type (i.e., dairy, dry and heifers), where NC is the average monthly animal type count at the farm, for dry matter intake (DM), volatile solid outputs (VS) and dietary nutrient values of crude protein $(\mathrm{CP})$, non-detergent fiber (NDF), dietary fats expressed as ether extract (EE), and ash (all in \%).

\begin{tabular}{|c|c|c|c|c|c|c|c|c|}
\hline Cow Type & NC & $\begin{array}{l}\text { Weight } \\
\text { (kg) }\end{array}$ & $\begin{array}{c}\mathrm{DM} \\
\left(\mathrm{kg} \mathrm{day}^{-1}\right)\end{array}$ & $\begin{array}{c}\text { VS } \\
\left(\mathrm{kg} \mathrm{Day}^{-1}\right)\end{array}$ & $\begin{array}{c}\mathrm{CP} \\
\text { (\% DM) }\end{array}$ & $\begin{array}{c}\text { NDF } \\
\text { (\% DM) }\end{array}$ & $\begin{array}{c}\mathrm{EE} \\
(\% \mathrm{DM})\end{array}$ & $\begin{array}{c}\text { Ash } \\
\text { (\% DM) }\end{array}$ \\
\hline Dairy & 383 & $650(65)$ & $22.2(8.6)$ & $7.67(1.26)$ & $\begin{array}{c}14.9 \\
(0.92)\end{array}$ & $\begin{array}{c}31.4 \\
(5.11)\end{array}$ & $3.8(0.26)$ & $6.1(1.00)$ \\
\hline Dry & 53 & $680(68)$ & $14.3(2.3)$ & $4.90(0.39)$ & $9.3(1.34)$ & $\begin{array}{c}30.3 \\
(3.41)\end{array}$ & $2.0(0.17)$ & $6.1(1.42)$ \\
\hline Heifer & 311 & $400(40)$ & $6.0(2.6)$ & $2.05(0.19)$ & $\begin{array}{c}16.3 \\
(2.02)\end{array}$ & $\begin{array}{c}40.1 \\
(2.74)\end{array}$ & $3.5(0.20)$ & $7.1(0.94)$ \\
\hline
\end{tabular}

Monthly feed refusal ranged from $5 \%$ to $12.5 \%$ of DM, similar to IPCC values. Feed refusal was sold and thus treated as $\mathrm{C}$ leaving the farm boundaries. We estimated monthly enteric $\mathrm{CH}_{4}$ emissions by different cattle groups following IPCC guidelines [38]:

$$
E_{C H_{4}, \text { enteric }}=\frac{G E I \times \frac{Y_{m}}{100}}{55.65}
$$

where $Y_{m}$ is the $\mathrm{CH}_{4}$ conversion factor (6.5 for dairy cows, 5.8 for dry cows and 3.0 for heifers). The factor 55.65 is the energy content of methane and GEI is gross energy intake, calculated by multiplying DM intake with gross energy (GE; Mcal kg-1), which was estimated from nutritional values of diets fed to cattle following Weiss and Tebbe [56]:

$$
G E=0.045 \times C P+0.094 \times E E+(100-C P-E E-A s h) \times 0.042
$$

where $E E$ is fat content (\%) and Ash (\%) is the total mineral content of a forage diet, expressed as weighted average percentages of DM. The residual (100-CP-EE-Ash) was assumed to be mostly polysaccharides [56]. Values of GE were converted to $\mathrm{MJ} \mathrm{kg}^{-1}$. Cattle $\mathrm{CO}_{2}$ emissions were estimated from DM and average cow body weights (BW; Table 2):

$$
E_{\mathrm{CO}_{2}, \text { enteric }}=-1.4+0.42 \times D M+0.045 \times B W^{0.75}
$$

\subsubsection{Manure Emissions}

Methane manure emissions ( $E_{\mathrm{CH}_{4}, \text { manure }}$ ) were calculated following IPCC guidelines [38], where $B_{0}$ was the maximum methane producing capacity for dairy cows set at 0.24 for North America, MS was the fraction of manure handled by the management system (in \%). Due to manure field applications during spring and fall, MS values were set at 90 (January, February, November, December), 50 (March, August, September, October) and 10 (April-July). Monthly methane conversion factors $(M C F ; \%)$ 
for the liquid manure management system on site were set at 10 (January, February, December), 20 (March-May and November), and 30 (June-October) from IPCC guidelines [38]. Manure $\mathrm{CH}_{4}$ emissions were estimated using total monthly VS inputs to the manure system as follows:

$$
E_{\mathrm{CH}_{4}, \text { manure }}=B_{0} \times 0.67 \times V S \times \frac{M S}{100} \times \frac{M C F}{100}
$$

Nitrogen Oxide $\left(\mathrm{N}_{2} \mathrm{O}\right)$ emissions from animal manure were estimated following IPCC Tier 2 guidelines [38] using DM intake and $C P$ as:

$$
N_{\text {intake }}=\frac{D M \times \frac{C P}{100}}{6.25}
$$

$\mathrm{N}$ excretion $\left(N_{\text {excretion }}\right)$ was calculated using default values for nitrogen retention rates $\left(N_{\text {ret, fraction }}\right.$; $\mathrm{kg} \mathrm{N}$ for $1000 \mathrm{~kg}$ animal mass day ${ }^{-1}$ ) for dairy cows in North America and estimates on $\mathrm{N}$ intake:

$$
N_{\text {excretion }}=N_{\text {intake }} \times\left(1-N_{\text {ret, fraction }}\right)
$$

where $N_{\text {ret,fraction }}$ was 0.2 for dairy cows and 0.07 for dry cows and heifers. Direct emissions were estimated to be 0 during winter months, when average monthly temperature was below $0{ }^{\circ} \mathrm{C}$ and a factor $E F_{\mathrm{N}_{2} \mathrm{O}}$ of 0.005 (uncertainty of 0.01 ) was multiplied by $N_{\text {excretion, }}$, as direct emissions for spring, summer and fall months while manure storage was liquid (with natural crust):

$$
E_{N_{2} \mathrm{O}, \text { manure }}=N_{\text {excretion }} \times \frac{M S}{100} \times E F_{N_{2} \mathrm{O}}
$$

Finally, indirect emissions from volatilization to $\mathrm{NH}_{3}$ and $\mathrm{NOx}\left(E_{\mathrm{N}_{2} \mathrm{O}, \mathrm{vol}}\right)$ and possible emissions from $\mathrm{N}$ leaching $\left(E_{\mathrm{N}_{2} \mathrm{O} \text {, leach }}\right)$ from the manure pit were estimated as follows:

$$
\begin{gathered}
E_{N_{2} O, v o l}=\left(N C * N_{\text {vol, fract }}\right) \times E F_{N, \text { vol }} \times \frac{44}{28} \\
E_{N_{2} \mathrm{O}, \text { leach }}=\left(N C * N_{\text {leach, fract }}\right) \times E F_{N, \text { leach }} \times \frac{44}{28}
\end{gathered}
$$

where $N_{\text {vol, fract }}$ was 0.48 (for liquid/slurry manure storage), $N_{\text {leach, fract }}=0.01, E F_{N, v o l}=0.01$ (assumed to be minimal), and $E F_{N, \text { leach }}=0.0075$, as suggested by IPCC guidelines [38].

\subsubsection{Field Emissions}

Emissions from manure and fertilizer applications were estimated using data from the farm nutrient management plan, which included liquid manure and bedding application by field, as well as fertilizer applications like urea (on corn fields), diammonium phosphate and potassium chloride (which were mainly applied on soybean and alfalfa fields). Urea contains approximately $20 \%$ carbon, which was assumed to gas out completely within one week of application [38,57]. The carbon was then converted to $\mathrm{kg} \mathrm{CO}_{2}$ using the conversion factor of 44/12. For $\mathrm{N}_{2} \mathrm{O}$ emissions from urea applications we assumed a conversion factor of $0.00242 \mathrm{~kg} \mathrm{~N}_{2} \mathrm{O}$ per $\mathrm{kg}$ of $\mathrm{N}$ applied. Urea applications only occurred during spring months (March) in 2018.

\subsubsection{C exports from Milk Production and Diesel Usage}

Carbon exports from milk were estimated following Felber et al. [58] assuming that milk contains $20.8 \pm 1.9 \mathrm{~g} \mathrm{C} \mathrm{MJ}^{-1}$ energy corrected milk (ECM; $\mathrm{kg}$ ), adjusted to $3.14 \mathrm{MJ} \mathrm{kg}^{-1}$ based on Tyrell and Reid [59]:

$$
C M=(0.327 \times \text { milk })+(12.95 \times f a t)+(7.65 \times \text { protein })
$$


where milk, fat and protein were in $\mathrm{kg}$, taken from 2 milk test days per month in 2018. Monthly milk exports were estimated by multiplying daily bulk tank measurements (AgSource Dairy; Verona, WI, USA) by the number of days in each month.

$\mathrm{CO}_{2}$ emissions from on-farm diesel use (from manure spreading, harvesting operations, etc.) were estimated following Rotz et al. [60] assuming a conversion factor of $2.637 \mathrm{~kg} \mathrm{CO}_{2}$ per liter of diesel consumed. We did not treat diesel fuel as imported $\mathrm{C}$, as we wanted to quantify its contribution to the overall GHG budget of the farm and because we did not consider fuel as a stable carbon storage product.

We converted all barnyard, manure, field and diesel emissions, as well as $\mathrm{C}$ exports from harvest and milk (Supplementary Materials Table S3) to $\mathrm{CO}_{2}$-eq (100 yr. greenhouse warming potential; GWP) [61] to quantify if farm NPP for 2018 offset emissions from within the farm boundaries, as well as to establish the source of emissions with the greatest impact on global warming [62]. Conversion factors from the respective radiative forcing of an emitted gas reaching the atmosphere were 298 and 25 for $\mathrm{N}_{2} \mathrm{O}$ and $\mathrm{CH}_{4}$ emissions, respectively [61].

\subsection{Uncertainty Analysis}

Uncertainty for remote sensing NPP was estimated by propagating GPP and $\mathrm{R}_{\text {eco }}$ standard deviations as follows:

$$
s d_{X}=\sqrt{\sum\left(s d_{X, \text { month }}\right)^{2}}
$$

where $s d_{X}$ is the mean annual (and seasonal) standard deviation estimated for $\mathrm{X}=\mathrm{GPP}$ or $\mathrm{R}_{\mathrm{eco}}$ for each crop field and natural vegetation type. We then calculated the annual (and seasonal) percent error for NPP by averaging errors for GPP and $R_{\text {eco }}$, respectively, using $s d_{X}$ divided by annual (and seasonal) summed GPP and $R_{\text {eco. }}$. We estimated harvest NPP uncertainty by varying root fractions by $\pm 30 \%$. Our confidence in HI and resulting residual data was high, thus excluded here from uncertainty measurements.

Cattle diet nutrient intake and volatile solid output uncertainties were estimated using nutrient variations from laboratory analyses of forage for $\mathrm{CP}$, Ash, EE and NDF. In addition, we varied dry matter intake by $\pm 10 \%$ as the average uncertainty taken from feed refusal data, which was propagated to VS outputs. These uncertainties were then propagated to $\mathrm{CH}_{4}$ and $\mathrm{N}_{2} \mathrm{O}$ manure emissions, as well as cattle $\mathrm{CO}_{2}$ and $\mathrm{CH}_{4}$ emissions, in addition to including standard deviations for feed dry matter (for enteric $\mathrm{CO}_{2}$ ) and gross energy (for enteric $\mathrm{CH}_{4}$ ) intakes and body weights for each cattle group. For direct $\mathrm{N}_{2} \mathrm{O}$ emissions we also incorporated suggested uncertainties of $\pm 50 \%$ from IPCC reports. For volatile $\mathrm{N}_{2} \mathrm{O}$ emissions from the manure pit we varied the fraction of volatile gas from $15 \%$ to $60 \%$ for liquid manure as suggested by IPCC guidelines [38]. For $\mathrm{N}$ losses from leaching we varied the fraction of leaching by $\pm 10 \%$ [63]. For each calculation step we estimated the percent variability which was then propagated to the next calculation step and finally to the parameter of interest (i.e., enteric, manure and field emissions) for each month.

Uncertainty for $\mathrm{C}$ milk exports were estimated from fat, protein and milk energy content variations taken from two milk test day results per month. Uncertainty was then propagated for each season by also including the variability in $\mathrm{C}$ milk contents per milk energy content from Felber et al. [58]. Uncertainties for diesel emissions were assumed to be low and set at $10 \%$, as purchase records were available.

\section{Results}

\subsection{Climate}

Our study farm is located in a temperate mid-continental climate, with cold winters and warm, wet summers. In 2018, average monthly air temperatures increased above $0{ }^{\circ} \mathrm{C}$ in May, followed by temperatures above $20^{\circ} \mathrm{C}$ from June through September (Supplementary Materials Figure S1). 
Accumulated photosynthetic active radiation (PAR) for 16 days around the acquisition dates of Landsat pictures was above $500 \mathrm{~mol}$ from March through the beginning of August, declining to 400-300 mol per 16 days from mid-August through the end of September. Annual rainfall amounted to approximately $1300 \mathrm{~mm}$ in 2018, which was $\sim 400 \mathrm{~mm}$ higher compared to long-term records [64], with May and August receiving the largest amounts with $>200 \mathrm{~mm}$ of rain.

\subsection{Net Carbon Budget}

Prairie du Sac farm was a large carbon sink for 2018, where net primary productivity (NPP) amounted to 7.25 million $\mathrm{kg} \mathrm{C}$ (= 26.6 million $\mathrm{kg}$ of $\mathrm{CO}_{2}$; Figure 2), and total emissions (i.e., $\mathrm{CO}_{2}, \mathrm{CH}_{4}$ and $\mathrm{N}_{2} \mathrm{O}$ from manure, soil and cattle) were 6.69 million $\mathrm{kg}$ of $\mathrm{CO}_{2}$-eq (Figure 3 and Supplementary Materials Figures S2-S4). When expressed in area needed to offset farm emissions for $~ 750$ dairy cattle, the farm would need to produce either corn, alfalfa, soybeans or wheat on $2.97,2.46,2.92$ or $3.0 \mathrm{~km}^{2}$ of land, respectively, and the respective crop products would need to remain within the farm boundaries (Table 3). For natural vegetation either forests, shrub and grasslands would have to make up 2.82, 2.98 and $2.79 \mathrm{~km}^{2}$ to offset farm emissions, respectively. A farm with only pasture vegetation would require $2 \mathrm{~km}^{2}(\sim 0.25$ ha per cow) in size to offset emissions for 2018 .

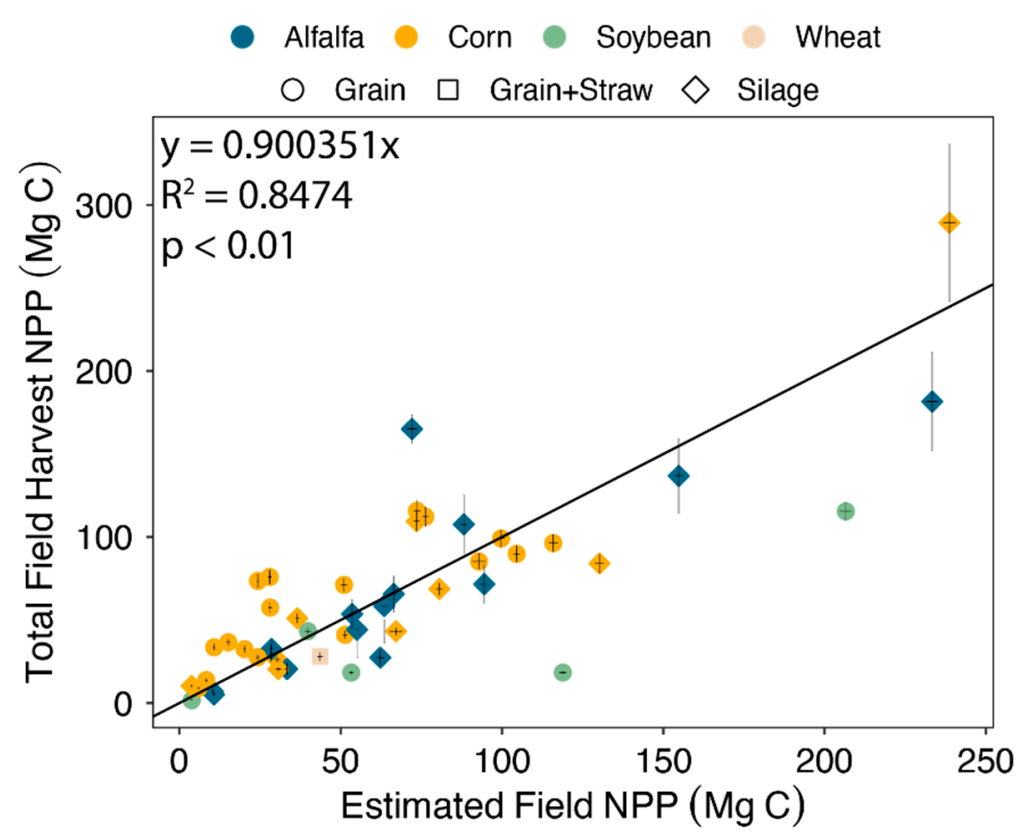

Figure 2. Correlation of estimated total annual sums of net primary productivity (NPP) from remote sensing data of cropfields versus harvest NPP. Harvest NPP was calculated from harvest indices and root:shoot ratios for alfalfa, corn, soybeans and winter wheat. Each point represents one field at Prairie $\mathrm{du}$ Sac farm. Error bars on the x-axis represent standard deviations of NPP estimated for each cropfield and on the y-axis propagated standard deviations for crop NPP, estimated by varying root:shoot ratios. 


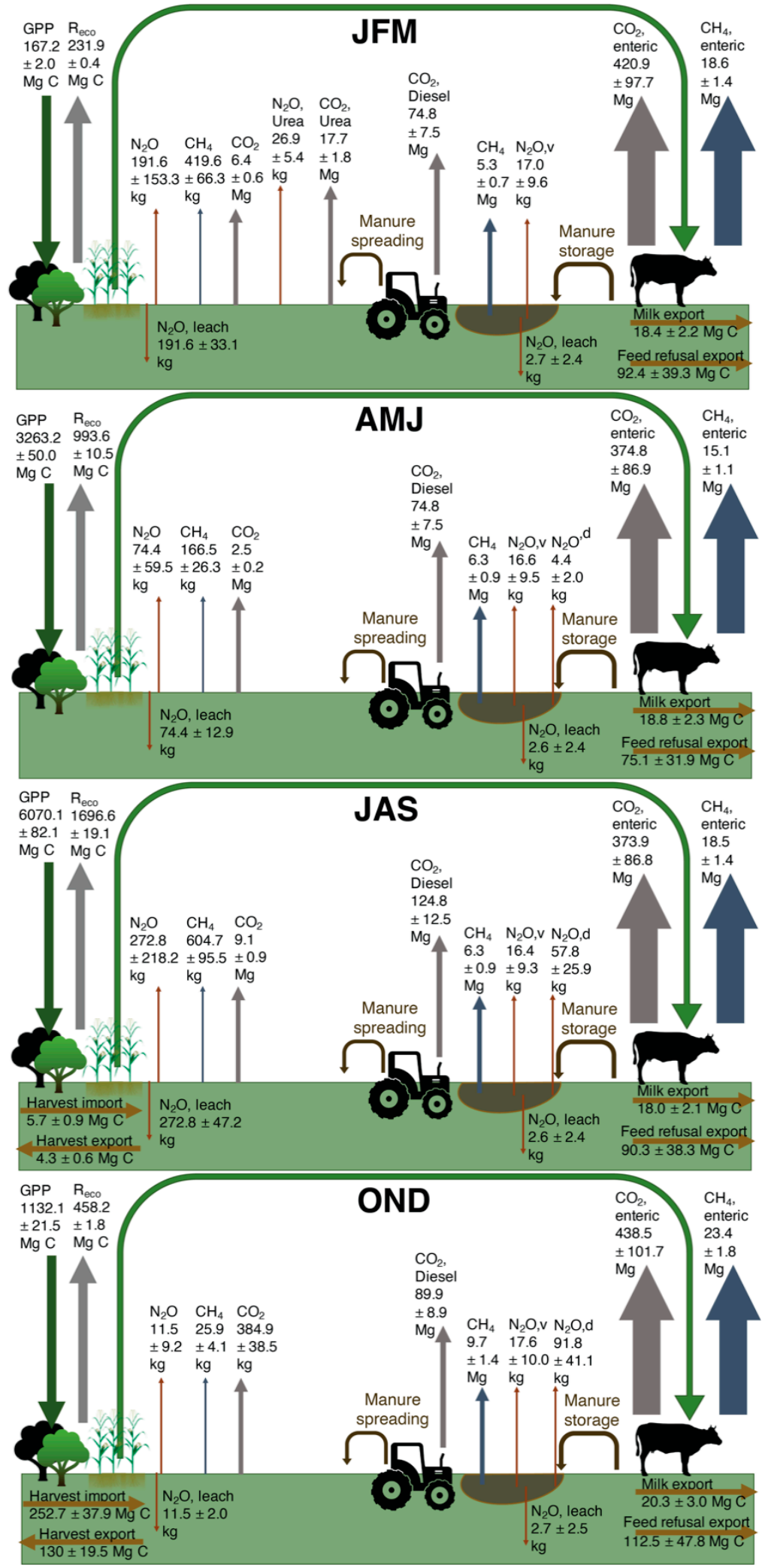

Figure 3. Seasonal schematics for $\mathrm{C}$ fluxes. $\mathrm{C}$ fluxes represent gross primary productivity (GPP) and ecosystem respiration $\left(\mathrm{R}_{\mathrm{eco}}\right), \mathrm{C}$ exports from milk, harvest and feed refusals, as well as greenhouse gas emissions from diesel $\left(\mathrm{CO}_{2}\right.$, Diesel) livestock (enteric fermentation of $\mathrm{CO}_{2}$, enteric and $\mathrm{CH}_{4}$, enteric), manure pit storage $\left(\mathrm{CH}_{4}\right.$ and direct $\left(\mathrm{N}_{2} \mathrm{O}, \mathrm{d}\right)$, volatile $\left(\mathrm{N}_{2} \mathrm{O}, \mathrm{v}\right)$ and leached $\left(\mathrm{N}_{2} \mathrm{O}\right.$, leach) nitrogen oxide emissions) and field $\left(\mathrm{N}_{2} \mathrm{O}, \mathrm{CH}_{4}\right.$ and $\mathrm{CO}_{2}$ emissions from manure and fertilizer applications). Seasons are separated by January, February, March (JFM), April, May, June (AMJ), July, August, September (JAS) and October, November, December (OND). 
Table 3. Annual Net primary productivity (NPP) by vegetation type, and estimated areas needed and actual covered area of each vegetation type to offset annual greenhouse gas emissions from Prairie du Sac dairy farm in 2018. The last column shows the area needed to offset emissions of one dairy cow (in ha).

\begin{tabular}{cccccc}
\hline Vegetation & $\begin{array}{c}\text { Total NPP } \\
\mathbf{( k g ~ C )}\end{array}$ & $\begin{array}{c}\text { NPP } \\
\mathbf{k g ~ C ~}^{\mathbf{2}} \mathbf{)}\end{array}$ & $\begin{array}{c}\text { Area Needed to } \\
\text { Offset } \\
\left.\text { Emissions } \mathbf{( k m}^{\mathbf{2}}\right)\end{array}$ & $\begin{array}{c}\text { Actual Area } \\
\text { Covered (\%) }\end{array}$ & $\begin{array}{c}\text { Area Needed } \\
\text { per Cow (ha) }\end{array}$ \\
\hline Alfalfa & $1,217,208$ & 0.77 & 2.46 & 64 & 0.33 \\
Corn & $1,364,220$ & 0.64 & 2.97 & 72 & 0.40 \\
Forest & 923,831 & 0.67 & 2.82 & 49 & 0.38 \\
Grass & $1,867,659$ & 0.68 & 2.79 & 99 & 0.37 \\
Pasture & 334,542 & 0.95 & 1.99 & 18 & 0.27 \\
Shrub & 626,255 & 0.63 & 2.98 & 33 & 0.40 \\
Soybean & 601,760 & 0.65 & 2.92 & 32 & 0.39 \\
Wheat & 317,883 & 0.63 & 3.01 & 17 & 0.40 \\
\hline
\end{tabular}

\subsection{Seasonal Greenhouse Gas Budget}

Croplands were large C sources for the first three months in 2018, followed by forest, grass and shrublands, whereas pastures were carbon sinks throughout all seasons (Supplementary Materials Figure S4). Forest, grass and shrublands were the largest $C$ sinks for April, May and June months, whereas croplands sequestered more $C$ during the months of July, August and September (Supplementary Materials Figures S3-S5). Overall, perennial vegetation like pastures and alfalfa had longer growing season and thus contributed to seasonal $C$ sequestration more compared to annual counterparts like corn or soybeans (Supplementary Materials Figure S3). Winter wheat fields were only photosynthetically active from April through the end of July, when the crop started to senesce, and seeds were ready to be harvested. Corn had sequestered the highest $\mathrm{g} \mathrm{C} \mathrm{m}^{-2}$ day $^{-1}$ compared to other vegetation types during July, when temperatures were highest, followed by alfalfa. Soybean crops had low photosynthetic activity during early summer but were similar to corn and alfalfa fields from the end of July through October. Photosynthetic activity and respiration at the farm were low during winter months (December-February and March) when temperatures were below $0{ }^{\circ} \mathrm{C}$. Alfalfa and corn were most productive, resulting in the highest biomass $C$ accumulation of all crops harvested at the site (Table 3). Soybeans and certain dry corn fields had the highest accumulation of residues, whereas most crop fields had a harvest index $(\mathrm{HI})$ of $>0.9$, leaving them mostly bare after harvest. Estimated NPP $(\mathrm{kg} \mathrm{C})$ from Landsat/MODIS data fusion correlated well with calculated whole plant NPP $(\mathrm{kg} \mathrm{C})$ from harvest data for each crop field $\left(R^{2}=0.85 ; p<0.001\right.$; Figure 2$)$, with greater variations for corn fields. The farm, as a whole, was a carbon source ( 13.6\%; NPP of -0.064 Gigagrams) for the first three months in 2018 (Figure 3) but sequestered more carbon during the rest of the year.

\subsection{Seasonal Non- $\mathrm{CO}_{2}$ Sources and Carbon Imports and Exports}

Emissions of $\mathrm{N}_{2} \mathrm{O}, \mathrm{CH}_{4}$ and $\mathrm{CO}_{2}$ from field manure applications $\left(191 \pm 153 \mathrm{~kg}\right.$ direct $\mathrm{N}_{2} \mathrm{O}$ emissions, $192 \pm 33 \mathrm{~kg}$ leached $\mathrm{N}_{2} \mathrm{O}$ emissions, $420 \pm 66 \mathrm{~kg} \mathrm{CH}_{4}$ emissions, $6357 \pm 636 \mathrm{~kg} \mathrm{CO}_{2}$ emissions; Figure 3) and urea (2189 $\pm 438 \mathrm{~kg} \mathrm{~N} 2 \mathrm{O}$ and $\left.4840 \pm 484 \mathrm{~kg} \mathrm{CO}_{2}\right)$ application contributed $\sim 11.2 \%$ to the overall $\mathrm{CO}_{2}$-eq exports $\left(2 \pm 0.3 \times 10^{6} \mathrm{~kg}\right)$ in January, February, and March (JFM), whereas enteric $\mathrm{CH}_{4}$ and $\mathrm{CO}_{2}$ emissions exhibited $51.5 \%$ of all $\mathrm{CO}_{2}$-eq exports $\left(464,960 \pm 34,872 \mathrm{~kg} \mathrm{CH}_{4}\right.$ and $420,920 \pm 97,653.4 \mathrm{~kg} \mathrm{CO} 2)$. Manure emissions $(132,067 \pm 18,621)$ contributed $8 \%$ to the overall $\mathrm{CO}_{2}$-eq export, and feed refusal 19.7\% $(92,424 \pm 39,262 \mathrm{~kg} \mathrm{C})$. Diesel emissions $\left(74,866 \pm 7487 \mathrm{~kg} \mathrm{CO}_{2}\right)$ and milk $\mathrm{C}$ exports $(18,410 \pm 2190 \mathrm{~kg} \mathrm{C})$ were the smallest sources for $\mathrm{CO}_{2}$-eq exports with $4.4 \%$ and $3.9 \%$, respectively (Figure 4). 


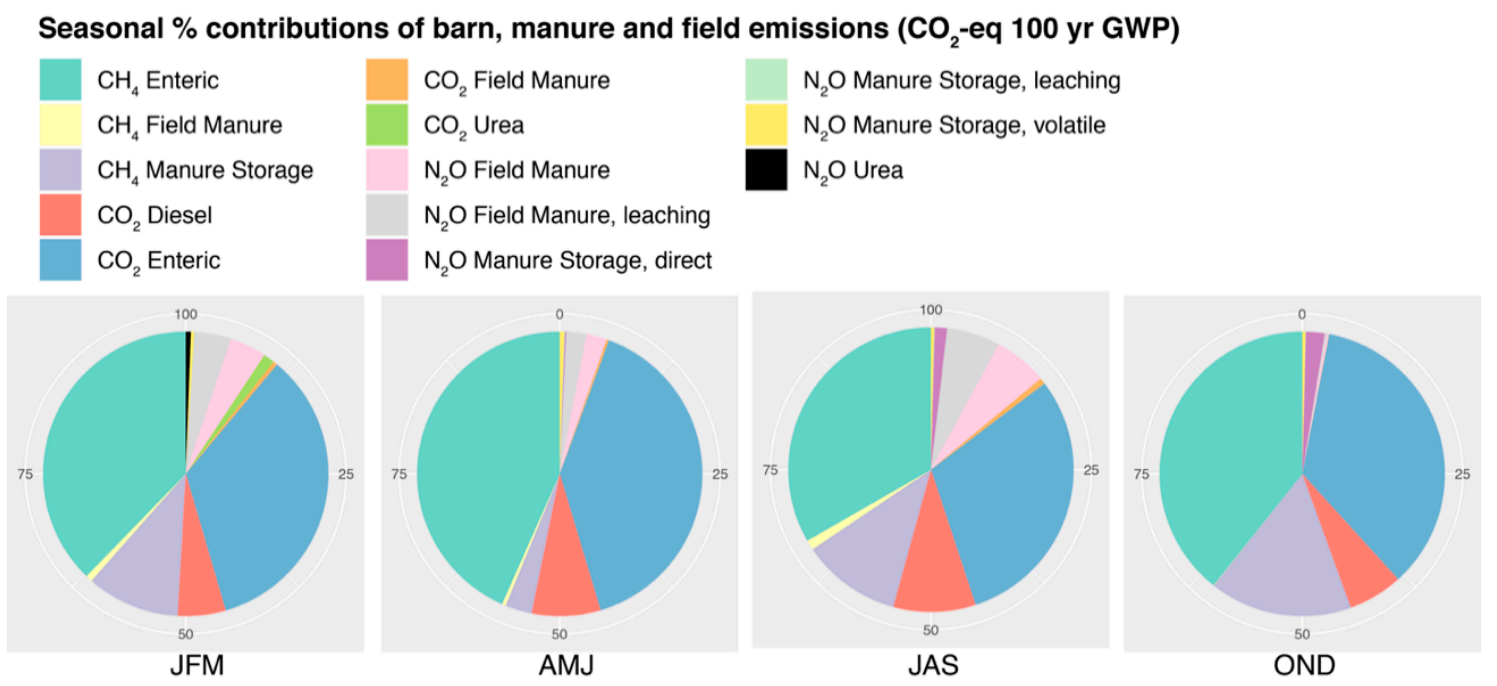

Figure 4. Percent contributions to total emissions of enteric fermentation, manure pit storage and field emissions of $\mathrm{CO}_{2}, \mathrm{CH}_{4}$ and $\mathrm{N}_{2} \mathrm{O}$, expressed as $100 \mathrm{yr} . \mathrm{CO}_{2}$-eq for each season in 2018. Seasons are separated by January, February, March (JFM), April, May, June (AMJ), July, August, September (JAS) and October, November, December (OND).

For late spring and summer months (April, May and June, AMJ; Figures 3 and 4) enteric fermentation $\left(376,589 \pm 28,244 \mathrm{~kg} \mathrm{CH}_{4}\right.$ and $\left.374,790 \pm 86,951 \mathrm{~kg} \mathrm{CO}_{2}\right)$ contributed the majority to all farm $\mathrm{CO}_{2}$-eq exports $\left(1 \pm 0.2 \times 10^{6} \mathrm{~kg}\right)$ with $58.8 \%$, followed by feed exports with $21.5 \%$ $(75,046.0 \pm 31,879.5 \mathrm{~kg} \mathrm{C})$, milk exports with $5.4 \%(18,836.4 \pm 2338.4 \mathrm{~kg} \mathrm{C})$ and diesel $\mathrm{CO}_{2}$ emissions of $5.9 \%\left(74,866 \pm 7487 \mathrm{~kg} \mathrm{CO}_{2}\right)$. Field manure and fertilizer applications $\left(74 \pm 60 \mathrm{~kg}\right.$ direct $\mathrm{N}_{2} \mathrm{O}$ emissions, $74 \pm 13 \mathrm{~kg}$ leached $\mathrm{N}_{2} \mathrm{O}$ emissions, $166 \pm 26 \mathrm{~kg} \mathrm{CH}_{4}$ emissions, $2498 \pm 250 \mathrm{~kg} \mathrm{CO}_{2}$ emissions) contributed $5.7 \%$ to all $\mathrm{CO}_{2}$-eq exports, followed by manure emissions $\left(2.6 \% ; 26,685 \pm 3763 \mathrm{~kg} \mathrm{CH}_{4}\right.$, $1302 \pm 583 \mathrm{~kg}$ direct $\mathrm{N}_{2} \mathrm{O}$ emissions, $4959 \pm 2817 \mathrm{~kg}$ volatile $\mathrm{N}_{2} \mathrm{O}$ emissions, $775 \pm 713 \mathrm{~kg} \mathrm{~N} \mathrm{~N}_{2} \mathrm{O}$ manure storage leaching).

In July, August and September (JAS; Figures 3 and 4), harvest imports from outside of the farm property slightly counteracted overall $\mathrm{C}$ emissions $\left(2 \pm 0.3 \times 10^{6} \mathrm{~kg}\right)$ by $\sim 1.2 \%$, but for October, November and December, farm imports lowered farm $\mathrm{CO}_{2}$-eq exports by $50.9 \%$. Nevertheless, farm exports (mostly soybeans) added $0.9 \%$ and $20.2 \%$ in JAS and OND, respectively, to exports $(2 \pm 0.3 \times$ $10^{6} \mathrm{~kg} \mathrm{CO}$-eq). For JAS enteric emissions $\left(18,490 \pm 1387 \mathrm{~kg} \mathrm{CH}_{4}\right.$ and $\left.373,923 \pm 86,750 \mathrm{~kg} \mathrm{CO}_{2}\right)$ made up $46.3 \%$ of all $\mathrm{CO}_{2}$-eq leaving the farm boundaries. $\mathrm{N}_{2} \mathrm{O}$ and $\mathrm{CH}_{4}$ emissions from the manure pit $\left(6295 \pm 888 \mathrm{~kg} \mathrm{CH}_{4}, 58 \pm 26 \mathrm{~kg}\right.$ direct $\mathrm{N}_{2} \mathrm{O}, 16 \pm 9 \mathrm{~kg}$ volatile $\mathrm{N}_{2} \mathrm{O}$ and $3 \pm 2$ emissions from leached $\left.\mathrm{N}_{2} \mathrm{O}\right)$ and emissions from manure and fertilizer applications $\left(273 \pm 218 \mathrm{~kg}\right.$ direct $\mathrm{N}_{2} \mathrm{O}$ emissions, $273 \pm 47 \mathrm{~kg} \mathrm{~N} \mathrm{~N}_{2} \mathrm{O}$ leaching, $605 \pm 96 \mathrm{~kg} \mathrm{CH}_{4}$ and $9090 \pm 909 \mathrm{~kg} \mathrm{CO}_{2}$ ) contributed $10 \%$ and $14.9 \%$, respectively. Diesel use (124,777 $\left.\pm 12,478 \mathrm{~kg} \mathrm{CO}_{2}\right)$ amounted to $6.9 \%$ of the overall emissions, whereas milk exports $(18,044 \pm 2148 \mathrm{~kg} \mathrm{C})$ accounted for $3.7 \%$ of the overall $\mathrm{CO}_{2}$-eq export. Feed exports $(90,230 \pm 38,330 \mathrm{~kg} \mathrm{C})$ were $18.3 \%$ of all $\mathrm{CO}_{2}$-eq exports.

For October, November and December (OND; Figures 3 and 4), emissions from enteric fermentation $\left(23,379 \pm 1754 \mathrm{~kg} \mathrm{CH}_{4}\right.$ and $\left.438,524 \pm 101,738 \mathrm{~kg} \mathrm{CO}_{2}\right)$ made up $54 \%$ of $\mathrm{CO}_{2}$-eq exports, followed by $15 \%$ for manure pit $\left(9696 \pm 1367 \mathrm{~kg} \mathrm{CH}_{4}, 92 \pm 41\right.$ direct $\mathrm{N}_{2} \mathrm{O}$ emissions, $18 \pm 10 \mathrm{~kg}$ volatile $\mathrm{N}_{2} \mathrm{O}$ and $2.7 \pm 2.5 \mathrm{~kg} \mathrm{~N} \mathrm{~N}_{2} \mathrm{O}$ emissions from $\mathrm{N}_{2} \mathrm{O}$ leaching) emissions and $21.9 \%$ from feed refusal $(112,498 \pm$ $47,789 \mathrm{~kg} \mathrm{C})$ exports. Milk C exports $(20,347 \pm 3008 \mathrm{~kg} \mathrm{C})$ contributed $4 \%$ and diesel $\mathrm{CO}_{2}(89,839 \pm$ $\left.8984 \mathrm{~kg} \mathrm{CO}_{2}\right)$ emissions $4.8 \%$ to all emissions. Field applications of manure and fertilizer $(12 \pm 9 \mathrm{~kg}$ direct $\mathrm{N}_{2} \mathrm{O}$ emissions, $12 \pm 2 \mathrm{~N}_{2} \mathrm{O}$ emissions from leaching, $26 \pm 4 \mathrm{~kg} \mathrm{CH}_{4}, 385 \pm 39 \mathrm{~kg} \mathrm{CO}_{2}$ ) only accounted for $0.6 \%$ of all emissions for OND. 


\section{Discussion}

\subsection{Remote Sensing as a Tool for GHG Budget Estimation}

Farm vegetation productivity is often derived from extensive field campaigns or, in more recent cases, using eddy covariance measurements [65], which may impose challenges due to time or funding constraints. Remote sensing techniques can significantly simplify this process at low cost [66]. Following objective one, we show that NPP estimated from remote sensing techniques gave exceptional correlations with farm harvest data for individual crop fields.

Remotely sensed NPP correlated well with NPP calculated from annual harvest estimates by field with greater variations for corn crops, likely due to differences in residue management for grain and silage corn (Figure 2). Larger uncertainties existed for alfalfa harvest GPP, due to the lack of belowground biomass data and greater variability in literature recorded root:shoot ratios. Overall remote sensing technologies to estimate NPP can be used to simplify carbon budget accounting for farms across the globe. Due to the relatively high resolution of Landsat images (30 by $30 \mathrm{~m}$ ) farmers can identify areas of low plant productivity, which could help to manage these areas using customized nutrient management to increase productivity [67]. Alternatively, such areas could be converted to pasture or grassland, to increase soil health and soil organic carbon (SOC) stocks. These practices could further contribute to increase farm $\mathrm{C}$ sequestration, by improving crop yields, and offsetting GHG emissions through plant biomass stocks [33].

\subsection{Seasonal GHG Budgets and Recommendations for Reducing GHG Emissions on Dairy Farms}

Following objective two, we show that the integrated crop-livestock farm in this study was a large carbon sink on an annual basis. The farm could offset the majority of farm emissions through $C$ sequestered by farm vegetation. Specifically, natural vegetation like forests, shrub- and grassland offset a large proportion of GHG emitted by the farm (Supplementary Materials Figure S4). Establishment and active stewardship of natural vegetation cover, such as the forest cover, may therefore serve as a potential mitigation strategy for dairy farm emissions [68]. The most vulnerable months for GHG emissions at Prairie du Sac were winter and early spring months (i.e., JFM and OND) as plant productivity was almost negligible when temperatures were low. For OND farm C exports made up $76 \%$ of $C$ imports from plant productivity. Nevertheless, harvest inputs added $\sim 18 \%$ to imported C, thus decreasing the $\mathrm{C}$ emission balance of the farm. Trading harvest products could be an attractive measure to offset farm emissions through interconnected farming systems, where farms serving as large carbon sinks due to their extensive vegetation areas could serve as $C$ donors through feed to smaller farms, which may exceed their GHG budget on a seasonal or annual basis [69]. Similarly, manure trading could increase farm sustainability [69], as field applications generally decrease GHG emissions, specifically of $\mathrm{CH}_{4}$ due to less anaerobic conditions (Figure 3), compared to long-term manure pit storage [70,71].

Our results show that there are a number of opportunities in feed, vegetation planting, and manure management that can significantly lower GHG emissions on dairy farms while maintaining production. Because pastures sequestered more carbon than they released back to the atmosphere even during winter months, their integration into cattle diets, given that feed conversion efficiency remains similar [71] at Prairie du Sac, could significantly lower the farm's C emissions throughout the first three months of the year (by at least 10\%), compared to other crops. Furthermore, perennial vegetation was shown to have lower overall soil GHG emissions compared to annual crops like corn [71], thus further highlighting the GHG mitigation potential of pastures for dairy farms. Additionally, improving field fertilizer and manure application strategies such as urea (here on corn fields) in conjunction with urease inhibiters could significantly decrease $\mathrm{N}$ losses and $\mathrm{N}_{2} \mathrm{O}$ emission from soils [72]. The reduction in GHG emissions from ruminants fed with grains is therefore just one part of the picture, as a more accurate accounting of emissions and milk production must include the $\mathrm{C}$ sequestered by feed 
crops [73]. Here, pastures had greater carbon uptake, highlighting the need to include farm practices in development of GHG budgets [73].

Enteric fermentation $\left(\mathrm{CH}_{4}\right.$ and $\left.\mathrm{CO}_{2}\right)$ made up the majority of GHG emissions at Prairie du Sac farm, highlighting the importance of herd size and diet in shaping GHG budgets of livestock farms [74]. Dairy cows emitted the majority of $\mathrm{CH}_{4}$ and $\mathrm{CO}_{2}$ through ruminal fermentation, because their rations were comparatively large with $22 \mathrm{~kg} \mathrm{DM}$, versus $14 \mathrm{~kg}$ and $6 \mathrm{~kg}$ for dry cows and heifers, respectively. Herd size and composition directly affect GHG budgets, and dairy breeds like Jerseys may significantly lower GHG emissions compared to Holsteins $[75,76]$.

Even though the size of the farm land base allowed for high plant productivity, more diesel was used to manage the farm landscape (i.e., manure applications, harvest, etc.), which resulted in relatively large diesel $\mathrm{CO}_{2}$ emissions of $364 \mathrm{Mg} \mathrm{CO}_{2}$ annually. That number is equivalent to annual GHG emissions of approximately 250 passenger vehicles (with an average emission rate of $\sim 136 \mathrm{~g}$ $\mathrm{CO}_{2} \mathrm{~km}^{-1}$ ) [77]. Reductions of such $\mathrm{CO}_{2}$ emissions could be accomplished through more efficient manure transport and applications systems, like dragline systems $[78,79]$. Feed refusal $\mathrm{C}$ exports were relatively large, thus a significant reduction in farm $C$ exports could be accomplished through more detailed feed intake knowledge of each individual cow and more controlled feed supply [80].

\subsection{ICLSs for Managing Dairy GHG Emissions}

Among GHG emission reduction practices, ICLSs may be one of the most sustainable approaches. ICLS farms can serve as sustainable agroecosystems, especially when management practices increase soil health and resilience to pests or weather extremes. Prairie du Sac ICLS farm was a large carbon sink in 2018, even when $C$ sequestration of natural vegetation from forests, shrub and grasslands was excluded, highlighting the importance of on-farm product recycling in offsetting GHG emissions [81]. Grassland and pastures together could offset all farm emissions on site, whereas shrublands, corn, wheat and soybean fields took up the least amount of carbon, due to their shorter growing season (Supplementary Materials Figure S4), thus more area would be needed to offset farm emissions. Corn and soybean production systems may also be unsustainable due to their impact on SOC losses [82], as their root:shoot ratios are comparatively small [38], adding little to increase soil carbon stocks $[69,83,84]$. Furthermore, the management of corn fields at the Prairie du Sac dairy farm accumulated limited soil $C$ because residues left on site were negligible, as the majority of the crop biomass was chopped for silage or baled for bedding following corn grain harvest. Alfalfa crops returned the highest amount of $\mathrm{C}$ to the system compared to all crops grown on site, as their root systems are more extensive than wheat, soybeans or corn crops. Perennials like alfalfa and pastures were productive earlier in the season compared to soybeans and corn, as their persistence of living belowground biomass allowed for more rapid leaf-out when temperatures were optimal [85]. Winter wheat, usually planted in the fall of the previous year, also showed earlier photosynthetic productivity (Supplementary Materials Figure S4). Nevertheless, earlier senescence of winter wheat plants (July) compared to alfalfa, corn and soybeans decreased their carbon sink potential compared to other crops.

Integrated crop-livestock systems can offset more barn and manure emissions, as harvested products remain within the farm boundaries [86]. In addition, pastures have a greater potential to remain carbon sinks throughout all seasons, even when harvested for feed or bedding [73]. Natural vegetation surrounding crop fields, such as forests, hedgerows or grasslands could offset farm emissions even of non-integrated dairy farms, given that $\sim 0.3-0.4$ ha of such land is allocated per cow. The largest $C$ sources were attributed to enteric fermentation, especially of dairy cows, due to differences in the nutritional composition of diets. Field and manure emissions were relatively low, showing the importance of an adequate land base per animal for manure application as an important part of ICLSs [9]. 


\section{Conclusions}

We show that remote sensing NPP provided an easy and cost-efficient way to estimate vegetation productivity. This analysis can be implemented to estimate GHG budgets and describe milk production not just in terms of animal efficiency but also in terms of environmental outcomes, thus giving a more complete picture of the sustainability of livestock farms. ICLS farms have great potential to increase agricultural sustainability, especially with strategic integration of perennial vegetation, as natural vegetation like forest, shrub, grass and pasture productivity offset farm emissions and on-farm harvest product recycling contributed to lower $\mathrm{C}$ exports. With a growing demand to feed an increasing population, intensification of livestock agriculture, specifically dairy, has come at the cost of increasing greenhouse gas emissions from unsustainable management practices [87,88]. Integrated crop-livestock systems have the potential to offset farm greenhouse gas emissions, as crop $\mathrm{C}$ sequestration through photosynthetic activity and plant biomass accumulation can offset GHG emissions produced within the farm boundaries [86].

Even though remotely sensed NPP in this study showed good correlations with annual harvest $\mathrm{NPP}$, this research could be improved by including greater temporal and spatial resolution of remotely sensed data (i.e., using hyperspectral drones). Greater resolution would allow for direct monthly comparisons of vegetation productivity and changes in monthly GHG emissions of the barnyard. In addition, in this study direct field measurements of cattle and field GHG emissions were not available for 2018 , therefore increasing the uncertainty around estimates, specifically regarding $\mathrm{N}_{2} \mathrm{O}$ emissions. Thus, for future work, field trials of monthly GHG soil emissions, particularly following manure and fertilizer applications, as well as barn $\mathrm{CO}_{2}$ and $\mathrm{CH}_{4}$ emissions from enteric fermentation, should be performed to reduce the uncertainty around these estimates.

Supplementary Materials: The following are available online at http://www.mdpi.com/2071-1050/12/3/765/s1, Figure S1: Meteorological variables for the acquisition dates of Landsat surface reflectance products, Figure S2: Estimated harvest net primary productivity by biomass component, Figure S3: Seasonal and spatial variations in net primary productivity of carbon (NPP) for 2018 at DFRC dairy farm, Prairie du Sac, Figure S4: Total sums of the carbon fluxes of gross primary productivity, ecosystem respiration and their sum net primary productivity for each season of 2018, Figure S5: Daily sums of gross primary productivity of C of forest, pastures, shrub and grasslands, as well as croplands, Table S1: Landsat and MODIS data availability for 2018, Table S2: Maximum quantum yield data and area covered at Prairie du Sac dairy, and Table S3: Average monthly milk production at the Dairy Forage Research Center dairy farm. Raw data of nutritional values for cattle diets, monthly cattle diet compositions and field harvest and manure and urea applications are in process of being archived in USDA Ag Data Commons (https://data.nal.usda.gov repository), DOI forthcoming prior to manuscript acceptance. In the interim, reviewers may access data at https://github.com/susewuse/DFRC_GHG2018.

Author Contributions: S.W. and A.J.D. acquired data. S.W. calculated the carbon fluxes and emissions and analyzed the data. A.R.D. helped with the calculation of remote sensing data. K.P.-B. helped with the statistical analysis. All authors contributed to writing of this manuscript. All authors have read and agreed to the published version of the manuscript.

Funding: This project was supported in part by an appointment to the Agricultural Research Services (ARS) Research Participation Program, administered by ORISE through the U.S. Department of Energy Oak Ridge Institute for Science and Education and the U.S. Department of Agriculture (USDA) Agricultural Research Services. Any opinions, findings, conclusions, or recommendations expressed in this publication are those of the authors and do not necessarily reflect the view of the U.S. Department of Agriculture.

Acknowledgments: We would like to thank the U.S. Dairy Forage Research Center and University of Wisconsin staff for their hard work on the farm and for providing herd and feed inventory as well as harvest data.

Conflicts of Interest: The authors declare no conflict of interest.

\section{References}

1. Food and Agriculture Organization of the United Nations. FAOSTAT Statistical Database. FAO: Rome, Italy, 2019. Available online: http://www.fao.org/faostat/en/\#data/QC (accessed on 25 July 2019).

2. Zhang, F.; Wang, Z.; Glidden, S.; Wu, Y.P.; Tang, L.; Liu, Q.Y.; Li, C.S.; Frolking, S. Changes in the soil organic carbon balance on China's cropland during the last two decades of the 20 th century. Sci. Rep. 2017, 7, 7144. [CrossRef] 
3. Sanderman, J.; Hengl, T.; Fiske, G.J. Soil carbon debt of 12,000 years of human land use. Proc. Natl. Acad. Sci. USA 2017, 114, 9575-9580. [CrossRef]

4. Scharlemann, J.P.; Tanner, E.V.; Hiederer, R.; Kapos, V. Global soil carbon: Understanding and managing the largest terrestrial carbon pool. Carbon Manag. 2014, 5, 81-91. [CrossRef]

5. Dong, F.; Hennessy, D.A.; Jensen, H.H. Size, Productivity and Exit Decisions in Dairy Farms. In Proceedings of the Agricultural and Applied Economics Association, Washington, DC, USA, 4-6 August 2013.

6. Cela, S.; Ketterings, Q.M.; Czymmek, K.; Soberon, M.; Rasmussen, C. Characterization of nitrogen, phosphorus, and potassium mass balances of dairy farms in New York State. J. Dairy Sci. 2014, 97, 7614-7632. [CrossRef] [PubMed]

7. White, R.R.; Hall, M.B. Nutritional and greenhouse gas impacts of removing animals from US agriculture. Proc. Natl. Acad. Sci. USA 2017, 114, E10301-E10308. [CrossRef] [PubMed]

8. Van Amburgh, M.E.; Russomanno, K.L.; Higgs, R.A.; Chase, L.E. Invited Review: Modifications to the Cornell Net Carbohydrate and Protein System related to environmental issues-Capability to evaluate nitrogen and phosphorus excretion and enteric carbon dioxide and methane emissions at the animal level. Appl. Anim. Sci. 2019, 35, 101-113. [CrossRef]

9. Saam, H.; Powell, M.J.; Jackson-Smith, D.B.; Bland, W.L.; Posner, J.L. Use of animal density to estimate manure nutrient recycling ability of Wisconsin dairy farms. Agric. Syst. 2005, 84, 343-357. [CrossRef]

10. Clay, N.; Garnett, T.; Lorimer, J. Dairy intensification: Drivers, impacts and alternatives. Ambio 2020, 49, 35-48. [CrossRef]

11. Garrett, R.D.; Niles, M.T.; Gil, J.D.B.; Gaudin, A.; Chaplin-Kramer, R.; Assmann, A.; Assmann, T.S.; Brewer, K.; de Faccio Carvalho, P.C.; Cortner, O.; et al. Social and ecological analysis of commercial integrated crop livestock systems: Current knowledge and remaining uncertainty. Agric. Syst. 2017, 155, 136-146. [CrossRef]

12. Tian, H.; Lu, C.; Pan, S.; Yang, J.; Miao, R.; Ren, W.; Yu, Q.; Fu, B.; Jin, F.-F.; Lu, Y.; et al. Optimizing resource use efficiencies in the food-energy-water nexus for sustainable agriculture: From conceptual model to decision support system. Curr. Opin. Environ. Sustain. 2018, 33, 104-113. [CrossRef]

13. Lapola, D.M.; Martinelli, L.A.; Peres, C.A.; Ometto, J.P.H.B.; Ferreira, M.E.; Nobre, C.A.; Aguiar, A.P.D.; Bustamante, M.M.C.; Cardoso, M.F.; Costa, M.H.; et al. Pervasive transition of the Brazilian land-use system. Nat. Clim. Chang. 2014, 4, 27-35. [CrossRef]

14. World Bank Agricultural land (\% of land area) | Data. Available online: http://www.data.worldbank.org. (accessed on 25 July 2019).

15. Bouwman, L.; Goldewijk, K.K.; Van Der Hoek, K.W.; Beusen, A.H.W.; Van Vuuren, D.P.; Willems, J.; Rufino, M.C.; Stehfest, E. Exploring global changes in nitrogen and phosphorus cycles in agriculture induced by livestock production over the 1900-2050 period. Proc. Natl. Acad. Sci. USA 2013, 110, 20882-20887. [CrossRef] [PubMed]

16. Erisman, J.W.; Galloway, J.N.; Seitzinger, S.; Bleeker, A.; Dise, N.B.; Petrescu, A.M.R.; Leach, A.M.; de Vries, W. Consequences of human modification of the global nitrogen cycle. Philos. Trans. R. Soc. B 2013, 368, 20130116. [CrossRef] [PubMed]

17. Howarth, R.W.; Boyer, E.W.; Pabich, W.J.; Galloway, J.N. Nitrogen use in the United States from 1961-2000 and potential future trends. Ambio J. Hum. Environ. 2002, 31, 88-96. [CrossRef]

18. Veltman, K.; Rotz, C.A.; Chase, L.; Cooper, J.; Ingraham, P.; Izaurralde, R.C.; Jones, C.D.; Gaillard, R.; Larson, R.A.; Ruark, M.; et al. A quantitative assessment of Beneficial Management Practices to reduce carbon and reactive nitrogen footprints and phosphorus losses on dairy farms in the US Great Lakes region. Agric. Syst. 2018, 166, 10-25. [CrossRef]

19. Villalba, G.; Liu, Y.; Schroder, H.; Ayres, R.U. Global phosphorus flows in the industrial economy from a production perspective. J. Ind. Ecol. 2008, 12, 557-569. [CrossRef]

20. Tian, H.; Lu, C.; Ciais, P.; Michalak, A.M.; Canadell, J.G.; Saikawa, E.; Huntzinger, D.N.; Gurney, K.R.; Sitch, S.; Zhang, B.; et al. The terrestrial biosphere as a net source of greenhouse gases to the atmosphere. Nature 2016, 531, 225-228. [CrossRef]

21. Bustamante, M.; Abad, C.R.; Harper, R.; Mbow, C.; Ravindranat, N.H.; Sperling, F.; Haberl, H.; de Siqueira Pinto, A.; Smith, P. Co-benefits, trade-offs, barriers and policies for greenhouse gas mitigation in the agriculture, forestry and other land use (AFOLU) sector. Glob. Chang. Biol. 2014, 20, 3270-3290. [CrossRef]

22. Reisinger, A.; Clark, H. How much do direct livestock emissions actually contribute to global warming? Glob. Chang. Biol. 2018, 24, 1749-1761. [CrossRef] 
23. Rotz, C.A. Modeling greenhouse gas emissions from dairy farms. J. Dairy Sci. 2018, 101, 6675-6690. [CrossRef]

24. Franzluebbers, A.J. Integrated crop-livestock systems in the Southeastern USA. Agron. J. 2007, 99, 361-372. [CrossRef]

25. Acosta-Martínez, V.; Bell, C.W.; Morris, B.E.L.; Zak, J.; Allen, V.G. Long-term soil microbial community and enzyme activity responses to an integrated cropping-livestock system in a semi-arid region. Agric. Ecosyst. Environ. 2010, 137, 231-240. [CrossRef]

26. Drinkwater, L.E.; Wagoner, P.; Sarrantonio, M. Legume-based cropping systems have reduced carbon and nitrogen losses. Nature 1998, 396, 262-265. [CrossRef]

27. Soussana, J.F.; Lemaire, G. Coupling carbon and nitrogen cycles for environmentally sustainable intensification of grasslands and crop-livestock systems. Agric. Ecosyst. Environ. 2014, 190, 9-17. [CrossRef]

28. Martins, A.P.; Costa, S.E.V.G.D.; Anghinoni, I.; Kunrath, T.R.; Cecagno, D.; Reichert, J.M.; Balerini, F.; Dillenburg, L.R.; Carvalho, P.C.D.F. Soil moisture and soybean physiology affected by drought in an integrated crop-livestock system. Pesqui. Agropecuária Bras. 2016, 51, 978-989. [CrossRef]

29. Pretty, J.N. Regenerating Agriculture: Policies and Practice for Sustainability and Self-Reliance; Earthscan Publications: London, UK, 1995; Volume 71, pp. 858-859.

30. Altieri, M.A. Agroecology: The science of natural resource management for poor farmers in marginal environments. Agric. Ecosyst. Environ. 2002, 93, 1-24. [CrossRef]

31. Altieri, M.; Nicholls, C.; Montalba, R. Technological approaches to sustainable agriculture at a crossroads: An agroecological perspective. Sustainability 2017, 9, 349. [CrossRef]

32. Peter, C.; Fiore, A.; Hagemann, U.; Nendel, C.; Xiloyannis, C. Improving the accounting of field emissions in the carbon footprint of agricultural products: A comparison of default IPCC methods with readily available medium-effort modeling approaches. Int. J. Life Cycle Assess. 2016, 21, 791-805. [CrossRef]

33. Olander, L.P.; Wollenberg, E.; Tubiello, F.N.; Herold, M. Synthesis and Review: Advancing agricultural greenhouse gas quantification. Environ. Res. Lett. 2014, 9, 075003. [CrossRef]

34. Preza Fontes, G.; Bhattarai, R.; Christianson, L.E.; Pittelkow, C.M. Combining environmental monitoring and remote sensing technologies to evaluate cropping system nitrogen dynamics at the field-scale. Front. Sustain. Food Syst. 2019, 3, 949. [CrossRef]

35. Bolinder, M.A.; Janzen, H.H.; Gregorich, E.G.; Angers, D.A.; VandenBygaart, A.J. An approach for estimating net primary productivity and annual carbon inputs to soil for common agricultural crops in Canada. Agric. Ecosyst. Environ. 2007, 118, 29-42. [CrossRef]

36. Agostini, F.; Gregory, A.S.; Richter, G.M. Carbon sequestration by perennial energy crops: Is the jury still out? Bioenergy Res. 2015, 8, 1057-1080. [CrossRef] [PubMed]

37. Saggar, S.; Giltrap, D.L.; Davison, R.; Gibson, R.; de Klein, C.A.M.; Rollo, M.; Ettema, P.; Rys, G. Estimating direct $\mathrm{N}_{2} \mathrm{O}$ emissions from sheep, beef, and deer grazed pastures in New Zealand hill country: Accounting for the effect of land slope on the $\mathrm{N}_{2} \mathrm{O}$ emission factors from urine and dung. Agric. Ecosyst. Environ. 2015, 205, 70-78. [CrossRef]

38. Eggleston, H.S.; Buendia, L.; Miwa, K.; Ngara, T.; Tanabe, K. (Eds.) 2006 IPCC Guidelines for National Greenhouse Gas Inventories; Prepared by the National Greenhouse Gas. Inventories Programme; IGES: Hayama, Japan, 2006.

39. Little, S.; Benchaar, C.; Janzen, H.; Kröbel, R.; McGeough, E.; Beauchemin, K. Demonstrating the effect of forage source on the carbon footprint of a Canadian dairy farm using whole-systems analysis and the Holos model: Alfalfa silage vs. corn silage. Climate 2017, 5, 87. [CrossRef]

40. Xiao, X. Modeling gross primary production of temperate deciduous broadleaf forest using satellite images and climate data. Remote Sens. Environ. 2004, 91, 256-270. [CrossRef]

41. Chandrasekara, K.; Sesha Sai, M.V.R.; Behera, G. Assessment of early season agricultural drought through land surface water index (LSWI) and soil water balance model. Int. Arch. Photogramm. Remote Sens. Spat. Inf. Sci. 2011, 38, 50-55. [CrossRef]

42. Sobrino, J.A.; Jiménez-Muñoz, J.C.; Paolini, L. Land surface temperature retrieval from LANDSAT TM 5. Remote Sens. Environ. 2004, 90,434-440. [CrossRef]

43. Avdan, U.; Jovanovska, G. Algorithm for automated mapping of land surface temperature using LANDSAT 8 Satellite Data. J. Sens. 2016, 2016, 1-8. [CrossRef] 
44. Xiao, X.; Hollinger, D.; Aber, J.; Goltz, M.; Davidson, E.A.; Zhang, Q.; Moore, B., III. Satellite-based modeling of gross primary production in an evergreen needleleaf forest. Remote Sens. Environ. 2004, 89, 519-534. [CrossRef]

45. Dong, J.; Xiao, X.; Wagle, P.; Zhang, G.; Zhou, Y.; Jin, C.; Torn, M.S.; Meyers, T.P.; Suyker, A.E.; Wang, J.; et al. Comparison of four EVI-based models for estimating gross primary production of maize and soybean croplands and tallgrass prairie under severe drought. Remote Sens. Environ. 2015, 162, 154-168. [CrossRef]

46. Madugundu, R.; Al-Gaadi, K.A.; Tola, E.; Kayad, A.G.; Jha, C.S. Estimation of gross primary production of irrigated maize using Landsat-8 imagery and Eddy Covariance data. Saudi J. Biol. Sci. 2016, 24, 410-420. [CrossRef] [PubMed]

47. Zhang, Y.; Xiao, X.; Wu, X.; Zhou, S.; Zhang, G.; Qin, Y.; Dong, J. A global moderate resolution dataset of gross primary production of vegetation for 2000-2016. Sci. Data 2017, 4, 170165. [CrossRef] [PubMed]

48. Gao, Y.; Yu, G.; Li, S.; Yan, H.; Zhu, X.; Wang, Q.; Shi, P.; Zhao, L.; Li, Y.; Zhang, F.; et al. A remote sensing model to estimate ecosystem respiration in Northern China and the Tibetan Plateau. Ecol. Model. 2015, 304, 34-43. [CrossRef]

49. Waring, R.H.; Landsberg, J.J.; Williams, M. Net primary production of forests: A constant fraction of gross primary production? Tree Phys. 1998, 18, 129-134. [CrossRef]

50. Peichl, M.; Brodeur, J.J.; Khomik, M.; Arain, M.A. Biometric and eddy-covariance based estimates of carbon fluxes in an age-sequence of temperate pine forests. Agric. Meteorol. 2010, 150, 952-965. [CrossRef]

51. Wutzler, T.; Lucas-Moffat, A.; Migliavacca, M.; Knauer, J.; Sickel, K.; Šigut, L.; Menzer, O.; Reichstein, M. Basic and extensible post-processing of eddy covariance flux data with REddyProc. Biogeosciences 2018, 15, 5015-5030. [CrossRef]

52. INRA; CIRAD; AFZ. The INRA-CIRAD-AFZ Tables: Composition and Nutritive Values of Feeds for Cattle, Sheep, Goats, Pigs, Poultry, Rabbits, Horses and Salmonids; INRA: Paris, France, 2002.

53. Anderson, T.; Hoffman, P. Nutrient Composition of Straw Used in Dairy Cattle Diets; University of Wisconsin: Madison, WI, USA, 2006.

54. Ishler, V.A.; Adams, R.S.; Heinrichs, A.J.; Varga, G.A. Concentrates for dairy cattle. 1994, Dairy and Animal Science Circular DAS 94-06, 1-16. Available online: https://animalscience.psu.edu (accessed on 1 January 2019).

55. Appuhamy, J.A.D.R.N.; Moraes, L.E.; Wagner-Riddle, C.; Casper, D.P.; Kebreab, E. Predicting manure volatile solid output of lactating dairy cows. J. Dairy Sci. 2018, 101, 820-829. [CrossRef]

56. Weiss, W.P.; Tebbe, A. Estimating digestible energy values of feeds and diets and integrating those values into net energy systems. Transl. Anim. Sci. 2018, 3, 953-961. [CrossRef]

57. Hasler, K.; Stefanie, B.; SWF, O.O.; Hans-Werner, O. Eco-innovations in the German fertilizer supply chain: Impact on the carbon footprint of fertilizers. Plant Soil Environ. 2017, 63, 531-544.

58. Felber, R.; Bretscher, D.; Münger, A.; Neftel, A.; Ammann, C. Determination of the carbon budget of a pasture: Effect of system boundaries and flux uncertainties. Biogeosciences 2016, 13, 2959-2969. [CrossRef]

59. Tyrrell, H.F.; Reid, J.T. Prediction of the energy value of cow's milk. J. Dairy Sci. 1965, 48, 1215-1223. [CrossRef]

60. Rotz, C.A.; Montes, F.; Chianese, D.S. The carbon footprint of dairy production systems through partial life cycle assessment. J. Dairy Sci. 2010, 93, 1266-1282. [CrossRef] [PubMed]

61. IPCC. Global Warming of $1.5^{\circ} \mathrm{C}$ : An IPCC Special Report on the Impacts of Global Warming of $1.5^{\circ} \mathrm{C}$ Above Pre-Industrial Levels and Related Global Greenhouse Gas Emission Pathways, in the Context of Strengthening the Global Response to the Threat of Climate Change, Sustainable Development, and Efforts to Eradicate Poverty; Masson-Delmotte, V., Zhai, P., Portner, H.O., Roberts, D., Skea, J., Shukla, P.R., Pirani, A., Moufouma-Okia, W., Pean, C., Pidcock, R., et al., Eds.; IPCC: Geneva, Switzerland, 2018.

62. Shine, K.P.; Fuglestvedt, J.S.; Hailemariam, K.; Stuber, N. Alternatives to the global warming potential for comparing climate impacts of emissions of greenhouse gases. Clim. Chang. 2005, 68, 281-302. [CrossRef]

63. Syswerda, S.P.; Basso, B.; Hamilton, S.K.; Tausig, J.B.; Robertson, G.P. Long-term nitrate loss along an agricultural intensity gradient in the Upper Midwest USA. Agric. Ecosyst. Environ. 2012, 149, 10-19. [CrossRef]

64. NCDC. Monthly Station Normals of Temperature, Precipitation, and Heating and Cooling Degree Days 1981-2010; National Climatic Data Center: Asheville, NC, USA, 2011. 
65. Baldocchi, D.D. Assessing the eddy covariance technique for evaluating carbon dioxide exchange rates of ecosystems: Past, present and future. Glob. Chang. Biol. 2003, 9, 479-492. [CrossRef]

66. Pasetto, D.; Castro, S.A.; Bustamante, J.; Casagrandi, R.; Chrysoulakis, N.; Cord, A.F.; Dittrich, A.; Marimon, C.D.; El Serafy, G.; Karnieli, A.; et al. Integration of satellite remote sensing data in ecosystem modelling at local scales: Practices and trends. Methods Ecol. Evol. 2018, 9, 1810-1821. [CrossRef]

67. Doughty, R.; Xiao, X.; Wu, X.; Zhang, Y.; Bajgain, R.; Zhou, Y.; Qin, Y.; Zou, Z.; McCarthy, H.; Friedman, J.; et al. Responses of gross primary production of grasslands and croplands under drought, pluvial, and irrigation conditions during 2010-2016, Oklahoma, USA. Agric. Water Manag. 2018, 204, 47-59. [CrossRef]

68. Leahy, S.C.; Kearney, L.; Reisinger, A.; Clark, H. Mitigating greenhouse gas emissions from New Zealand pasture-based livestock farm systems. Curr. Bot. 2019, 81, 101-110. [CrossRef]

69. Martin, G.; Moraine, M.; Ryschawy, J.; Magne, M.-A.; Asai, M.; Sarthou, J.-P.; Duru, M.; Therond, O. Crop-livestock integration beyond the farm level: A review. Agron. Sustain. Dev. 2016, 36, 53. [CrossRef]

70. Aguirre-Villegas, H.A.; Larson, R.A. Evaluating greenhouse gas emissions from dairy manure management practices using survey data and lifecycle tools. J. Clean. Prod. 2017, 143, 169-179. [CrossRef]

71. Wattiaux, M.A.; Uddin, M.E.; Letelier, P.; Jackson, R.D.; Larson, R.A. Invited Review: Emission and mitigation of greenhouse gases from dairy farms: The cow, the manure, and the field. Appl. Anim. Sci. 2019, 35, $238-254$. [CrossRef]

72. Tzemi, D.; Breen, J. Reducing greenhouse gas emissions through the use of urease inhibitors: A farm level analysis. Ecol. Model. 2019, 394, 18-26. [CrossRef]

73. Seó, H.L.S.; Machado Filho, L.C.P.; Brugnara, D. Rationally managed pastures stock more carbon than no-tillage Fields. Front. Environ. Sci. 2017, 5, 711. [CrossRef]

74. Koneswaran, G.; Nierenberg, D. Global farm animal production and global warming: Impacting and mitigating climate change. Environ. Health Perspect. 2008, 116, 578-582. [CrossRef]

75. Riva, A.D.; Kristensen, T.; De Marchi, M.; Kargo, M.; Jensen, J.; Cassandro, M. Carbon footprint from dairy farming system: Comparison between Holstein and Jersey cattle in Italian circumstances. Curr. Bot. 2014, 18, 75-80.

76. Capper, J.L.; Cady, R.A. A comparison of the environmental impact of Jersey compared with Holstein milk for cheese production. J. Dairy Sci. 2012, 95, 165-176. [CrossRef]

77. Sims, R.; Schaeffer, R.; Creutzig, F.; Cruz-Nunez, X.; D’Agosto, M.; Dimitriu, D.; Figueroa Meza, M.J.; Fulton, L.; Kobayashi, S.; Lah, O.; et al. Transport. In Climate Change 2014: Mitigation of Climate Change. Contribution of Working Group III to the Fifth Assessment Report of the Intergovern-Mental Panel on Climate Change; Edenhofer, O., Pichs-Madruga, P., Sokona, Y., Farahani, E., Kadner, S., Seyboth, K., Adler, A., Baum, I., Brunner, S., Eickemeier, P., et al., Eds.; Cambridge University Press: Cambridge, UK; New York, NY, USA, 2014.

78. Sørensen, C. A model of field machinery capability and logistics: The case of manure application. 2003. Available online: https://cigrjournal.org/index.php/Ejounral/article/view/413 (accessed on 1 August 2019).

79. Koelsch, R.K. G95-1266 Environmental considerations for manure application system selection. Hist. Mater. Univ. Neb. Linc. Ext. 1995, Jan, 1405.

80. De Ondarza, M.B.; Tricarico, J.M. Review: Advantages and limitations of dairy efficiency measures and the effects of nutrition and feeding management interventions. Prof. Anim. Sci. 2017, 33, 393-400. [CrossRef]

81. Lemaire, G.; Franzluebbers, A.; de Faccio Carvalho, P.C.; Dedieu, B. Integrated crop-livestock systems: Strategies to achieve synergy between agricultural production and environmental quality. Agric. Ecosyst. Environ. 2014, 190, 4-8. [CrossRef]

82. Moore, K.J.; Anex, R.P.; Elobeid, A.E.; Fei, S.; Flora, C.B.; Goggi, A.S.; Jacobs, K.L.; Jha, P.; Kaleita, A.L.; Karlen, D.L.; et al. Regenerating agricultural landscapes with perennial groundcover for intensive crop production. Agronomy 2019, 9, 458. [CrossRef]

83. McGowan, A.R.; Nicoloso, R.S.; Diop, H.E.; Roozeboom, K.L.; Rice, C.W. Soil organic carbon, aggregation, and microbial community structure in annual and perennial biofuel crops. Agron. J. 2019, 111, 128-142. [CrossRef]

84. Carvalho, J.L.N.; Hudiburg, T.W.; Franco, H.C.J.; DeLucia, E.H. Contribution of above- and belowground bioenergy crop residues to soil carbon. GCB Bioenergy 2017, 9, 1333-1343. [CrossRef] 
85. Tenuta, M.; Amiro, B.D.; Gao, X.; Wagner-Riddle, C.; Gervais, M. Agricultural management practices and environmental drivers of nitrous oxide emissions over a decade for an annual and an annual-perennial crop rotation. Agric. Meteorol. 2019, 276-277, 107636. [CrossRef]

86. Jansson, C.; Wullschleger, S.D.; Kalluri, U.C.; Tuskan, G.A. Phytosequestration: Carbon biosequestration by plants and the prospects of genetic engineering. BioScience 2010, 60, 685-696. [CrossRef]

87. Thornton, P.K. Livestock production: Recent trends, future prospects. Philos. Trans. R. Soc. B Biol. Sci. 2010, 365, 2853-2867. [CrossRef] [PubMed]

88. Godfray, H.C.J.; Garnett, T. Food security and sustainable intensification. Philos. Trans. R. Soc. B Biol. Sci. 2014, 369, 20120273. [CrossRef] [PubMed]

(C) 2020 by the authors. Licensee MDPI, Basel, Switzerland. This article is an open access article distributed under the terms and conditions of the Creative Commons Attribution (CC BY) license (http://creativecommons.org/licenses/by/4.0/). 